\title{
Laboratory Testing in the Era of Direct or Non- Vitamin K Antagonist Oral Anticoagulants: A Practical Guide to Measuring Their Activity and Avoiding Diagnostic Errors
}

\author{
Emmanuel J. Favaloro, PhD, FFSc (RCPA) ${ }^{1}$ Giuseppe Lippi, MD² \\ ${ }^{1}$ Department of Haematology, Institute of Clinical Pathology and \\ Medical Research (ICPMR), Pathology West, NSW Health Pathology, \\ Westmead, New South Wales, Australia \\ 2 Laboratory of Clinical Chemistry and Hematology, Academic Hospital \\ of Parma, Parma, Italy \\ Address for correspondence Emmanuel J. Favaloro, PhD, FFSc (RCPA), \\ Department of Haematology, Institute of Clinical Pathology and \\ Medical Research (ICPMR), Pathology West, Westmead Hospital, \\ Westmead, New South Wales, Australia \\ (e-mail: emmanuel.favaloro@health.nsw.gov.au).
}

Semin Thromb Hemost 2015;41:208-227.

\begin{abstract}
A new generation of antithrombotic agents has recently emerged. These provide direct inhibition of either thrombin (factor Ila [Flla]) or FXa, and are increasingly replacing the classical anticoagulants (heparin and coumarins such as warfarin) in clinical practice for a variety of conditions. These agents have been designated several acronyms, including NOACs, DOACs, and TSOACs, respectively, referring to new (novel; non-vitamin K antagonist) oral anticoagulants, direct oral anticoagulants, and target-specific oral anticoagulants, and currently include dabigatran (Flla inhibitor), and rivaroxaban, apixaban, edoxaban, and betrixaban (FXa inhibitors). The pervading mantra that NOACs do not require laboratory monitoring is countered by ongoing recognition that laboratory testing for drug effects is needed in many situations. Moreover, since these agents "do not require" laboratory monitoring, some clinicians inappropriately take this to mean that they do not affect hemostasis tests. This review aims to briefly review the laboratory studies that have evaluated the NOACs against a wide range of laboratory

\section{Keywords}

- NOACs

- dabigatran

- rivaroxaban

- apixaban

- edoxaban

- measurement

- interference assays to assess utility for qualitative or quantitative measurements of these drugs, as well as interferences that may cause misdiagnosis of hemostatic defects. Point of care testing, including use of alternate samples such as urine and serum, is also under development but is not covered extensively in this review. The main aims of this article are to provide practical guidance to general laboratory testing for NOACs, as well as to help avoid diagnostic errors associated with hemostasis testing performed on samples from treated patients, as these currently comprise major challenges to hemostasis laboratories in the era of the NOACs.
\end{abstract}

Anticoagulant therapy is typically applied to patients suffering from a variety of conditions, as associated with several prothrombotic risk factors, and primarily to treat or prevent several thromboembolic disorders. These typically include atrial fibrillation, acute coronary syndrome, prevention of venous thromboembolism (VTE) in patients undergoing major, orthopedic, or cancer surgery, therapy, and prevention of recurrence in patients with previous episodes of VTE. ${ }^{1}$ For decades, anticoagulant therapy has been based on the administration of two different classes of drugs, the vitamin $\mathrm{K}$ antagonists (VKAs; typically warfarin and acenocoumarol) and heparinoids, including unfractionated heparin (UFH), published online February 19, 2015
Issue Theme Anticoagulant Therapy: Present and Future; Guest Editor: Job Harenberg, MD.
Copyright @ 2015 by Thieme Medical Publishers, Inc., 333 Seventh Avenue, New York, NY 10001, USA. Tel: +1(212) 584-4662.
DOI http://dx.doi.org/ 10.1055/s-0035-1546827. ISSN 0094-6176. 
low-molecular-weight heparin (LMWH), as well as other heparin-like molecules such as fondaparinux. Although these classes of drugs have been proven effective for both primary and secondary prevention of systemic thromboembolism, they carry several drawbacks and limitations. ${ }^{1-3}$

Much of this background has been provided by us in a recent review, ${ }^{4}$ and hence will not be covered here again, except as overview. Thus, although VKAs are orally administered, they require careful laboratory monitoring by means of the international normalized ratio (INR) because of high interindividual variability in VKA sensitivity and because of considerable drug and food interactions. In contrast, the heparin drugs are administered parenterally (either intravenously or subcutaneously). Monitoring is typically undertaken for UFH (using an activated partial thromboplastin time [aPTT] or anti-Xa assay) but is not usually required for LMWH.

VKAs act by impairing the liver synthesis of vitamin $\mathrm{K}$-depended clotting factors (i.e., factors II [FII], VII, IX, and $\mathrm{X}$ ), thus generating a profound anticoagulant state mirrored by substantial prolongations of both prothrombin time (PT) and aPTT. In contrast, heparins act through selective inhibition of activated coagulation FIla and FXa, with a more prominent effect on FXa for LMWH and a more prominent effect on FIIa for UFH.

Both classes of drugs are effective clinical anticoagulants. ${ }^{1}$ Nevertheless, many drawbacks of both VKAs and LMWH make these drugs a suboptimal means of patient anticoagulation, and this has paved the way to development and commercialization of a new generation of antithrombotic agents. These were originally termed new (or novel) oral anticoagulants (NOACs), and later (as they were no longer new or novel) as direct oral anticoagulants (DOACs), although the terms target-specific oral anticoagulants (TSOACs), directspecific oral anticoagulants (DSOACs), and non-VKA oral anticoagulants (NOACs) have also been proposed. ${ }^{4,5}$ In keeping with other articles in this issue of the journal, we will adopt the abbreviation NOACs in the current review.

The NOACs have been specifically designed to provide direct inhibition of either FIla or FXa, and currently include dabigatran (as the only available direct FIla inhibitor), or rivaroxaban, apixaban, edoxaban, and betrixaban (as direct FXa inhibitors). ${ }^{4-7}$ These newer agents present several advantages compared with both VKAs and LMWH. First, like VKAs they are oral drugs, and thus avoid the need for injections as required for heparin therapy. Second, they are administered at fixed doses, are reportedly characterized by a more homogenous pharmacokinetic profile to generate a more predictable anticoagulant effect than either VKAs or heparins, thus theoretically requiring no, or perhaps more realistically less stringent, therapeutic measurements. ${ }^{4,7-9}$ The half-life of NOACs is also substantially lower than that of VKAs (i.e., 5-18 vs. $24-48$ hours), and this has the theoretical advantage that urgent reversal of the anticoagulant effect may be achieved by simple withdrawal of the drug. On the contrary, there are no currently available antidotes, clinically proven to achieve urgent reversal in the case of overdose or bleeding.

The efficacy and safety profile of the NOACs has also been proven by several studies, indeed concluding that NOACs display a more favorable risk-benefit profile than either VKAs or LMWH. The similar to superior efficacy in reducing the risk of thrombosis and systemic thromboembolism is coincidently associated with a much lower likelihood of major bleeding, especially cerebral bleeding, making these agents favored by clinicians and patients alike. ${ }^{6,7,10-12}$

Nevertheless, the pervading "mantra" that NOACs are also more practical than VKAs or LMWH because they do not require laboratory monitoring is not entirely true, and there are several situations in which laboratory assessment may be useful. $^{4,7,9}$ Although these agents are reported to display predictable pharmacokinetic profiles, their metabolism is complex, and entails enteric adsorption and liver or renal clearance. Thus, there are some drug interactions, as well as differential liver and renal influences, ${ }^{13}$ which may expose patients to a significant risk of over- or undercoagulation. Indeed, a wide range of plasma concentrations can actually be evidenced in population studies, ranging from below 20 to as high as 400 or more $\mathrm{ng} / \mathrm{mL}$ in different patients at different times postdosage (i.e., trough vs. peak), despite all time points reflecting "therapeutic levels." Unexpectedly, high or low plasma concentrations may also be evident in subgroups of patients that may alternatively need "personalized" dose adjustments to otherwise prevent bleeds or thrombosis while on standard doses. Finally, unanticipated events such as urgent surgery (or other invasive procedure) and unexpected pregnancy may require an evaluation of the status of a particular patient's drug level. These considerations define indications for laboratory testing to better define actual levels and/or drug anticoagulant effects. Additional "indications" for laboratory testing include onset of unexpected thrombotic or hemorrhagic events in patients on therapy, patients with extreme of body weight, abrupt impairment of renal and kidney function, suspicion of overdosage, or intoxication, along with assessment of real compliance with therapy. ${ }^{4,7,9}$

\section{Scope of Current Review}

The main aims of this article are (1) to briefly review the laboratory studies that have evaluated the NOACs against a wide range of laboratory assays to assess utility for qualitative ("screening") or quantitative measurements of these drugs along with test interferences that may cause misdiagnosis of hemostatic defects and (2) to provide practical guidance to laboratory testing for these agents, as well as to help avoid diagnostic errors associated with hemostasis testing performed on samples from treated patients. These concerns currently comprise major challenges to hemostasis laboratories in the era of the NOACs. Assessments related to point of care testing, and alternative sample types such as serum and urine, while mentioned, are largely covered elsewhere in this issue. ${ }^{9}$ Also, although an increasing number of articles are now reporting studies looking at reversal of these agents, we will only briefly overview this for completeness, as a thorough discussion of these studies would require a separate review. This review primarily covers the earlier NOACs, dabigatran, rivaroxaban, and apixaban, since there is substantial experience now with these agents, whereas there is insufficient 
information with the newer agents, edoxaban and betrixaban, to provide meaningful guidance. Edoxaban has only been recently cleared by the Food and Drug Administration, and approval by the European Medicines Agency is under current consideration. Betrixaban is still under clinical evaluation.

\section{Laboratory Testing for the NOACs}

The "therapeutic-based" testing of drugs including NOACs is classically based on direct assessment of their concentration in serum or plasma using liquid chromatography tandem mass spectrometry (LC-MS/MS) (or analogous) techniques, which are otherwise conventionally regarded as reference methods for establishing the actual concentration of these and other drugs. ${ }^{14}$ However, these methods, requiring sophisticated and expensive instrumentation, along with skilled personnel, are unavailable to most routine clinical laboratories, and do not accurately estimate the anticoagulant activity attributable to these drugs (including their metabolites). Even if available, long turnaround times for test results would also make these methods unsuitable for urgent testing. Thus, more practical tests are needed for clinical laboratories required to perform both routine and urgent assessment of NOACs.

As part of our assessment, we performed a Medline search using the following search term: (apixaban OR dabigatran OR rivaroxaban OR edoxaban OR DOAC OR NOAC OR TSOAC) AND (laboratory OR monitoring OR measurement OR test). The rationale for this approach was to perform a "simple" search that any laboratory or clinical practitioner might perform to gain an appreciation of the currently available information. The search was performed without restriction on language, date, or article type, and covered the period up to the end of November 2014. The search retrieved 1,109 records, which were then manually reviewed by title and abstract for relevance. The following articles were subsequently removed from further consideration: (1) articles that were review or opinion in nature and which did not substantially provide any new or novel data regarding laboratory testing; (2) articles that were restricted to assessments of LC-MS/MS or similar methodologies; (3) articles that could not be retrieved by us, or were in languages or in a form that we could not easily draw meaningful information; and (4) articles describing nonhuman-based studies (e.g., animal studies). Additional articles were added to our review, as either subsequently derived from an evaluation of the above studies (i.e., from the reference list), or else as otherwise known to us. The outcome of this process is summarized in - Fig. 1. Most articles contained data for dabigatran $(n=63)$ and rivaroxaban $(n=64)$, although a significant number also contained information for apixaban $(n=26)$; very few evaluated edoxaban $(n=5)$. This likely reflected the timeline for development, clinical release, and uptake of these drugs, with the sequence being dabigatran and rivaroxaban, followed by apixaban and then edoxaban. An evaluation of the timeline for these publications would also confirm this conclusion (-Fig. 2), as well as suggesting more information is yet to come (given increasing yearly numbers of publication). Approximately equal number of publications reported on in vitro versus ex vivo data, and a proportion of the studies evaluated reversal of drug effects. The main articles used to draw conclusions in this review are listed in Appendix A.

\section{Dabigatran}

A total of 63 articles described some form of laboratory-based testing for dabigatran, with many studies including routine coagulation tests (PT and aPTT) and/or direct thrombin

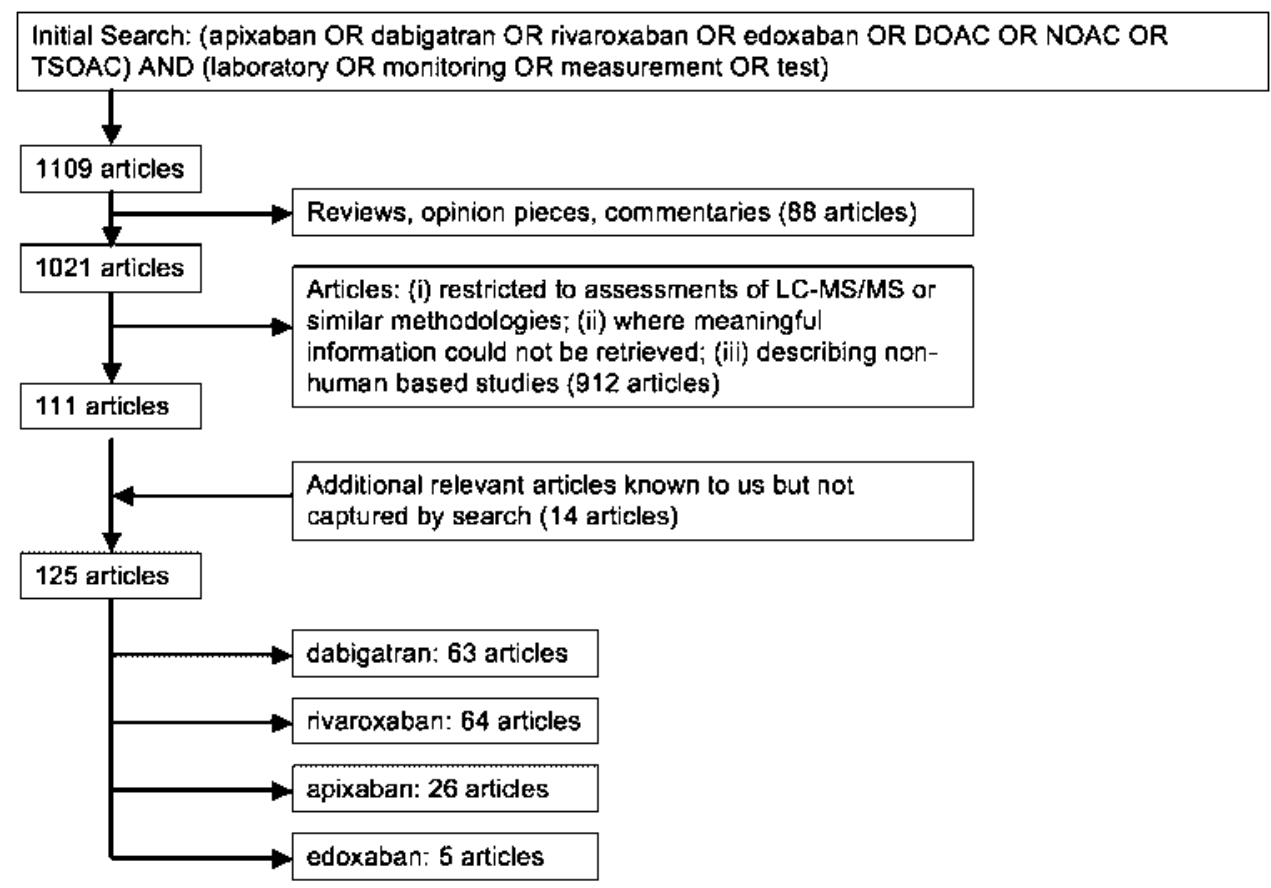

Fig. 1 A summary of the search strategy used to develop the major articles assessed to generate the current report. The final listing of the 125 articles is given in Appendix A. 


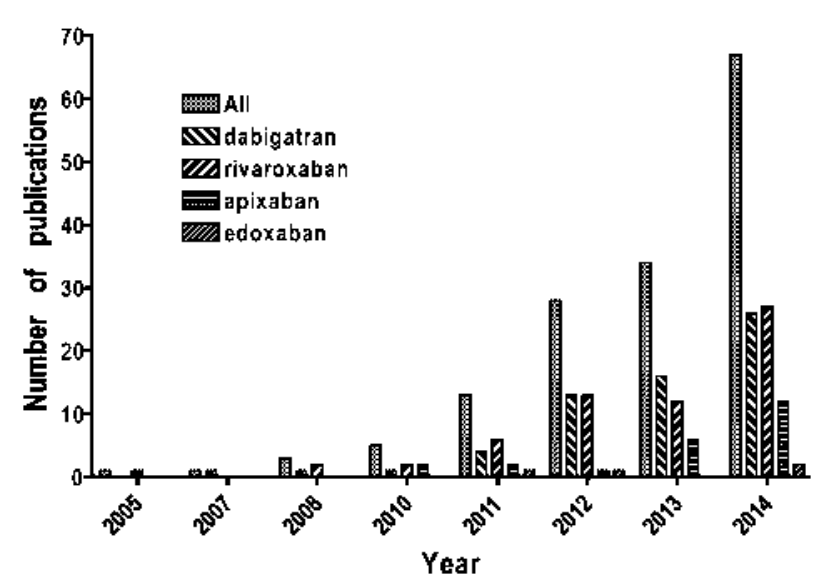

Fig. 2 Year of publication of the major articles is listed in Appendix A, as well as by NOAC evaluated.

inhibitor/dilute thrombin time (DTI/dTT) assays. Additional assays assessed included the "standard" TT, "dilute," or otherwise "modified" PT (dPT/mPT), anti-Xa, ecarin clotting time (ECT) or ecarin chromogenic assays (ECA), factor assays, protein $C$ (PC), protein S (PS), antithrombin (AT), activated $P C$ resistance (APCR), dilute Russell viper venom time (dRVVT), activated clotting time (ACT), prothrombinaseinduced clotting time (PICT), platelet function testing, von Willebrand factor (VWF) testing, thromboelastography/ rotational thromboelastometry (TEG/ROTEM), and thrombin generation assays (TGA).

Significant prolongations of PT, aPTT, and TT were invariably observed in most instances of measurable dabigatran concentration, although TT was most sensitive, followed by aPTT and PT, which was least sensitive of the three routine assays. ${ }^{15-41}$ There was some reagent-based sensitivity for both PT and aPTT, and there was some variability with respect to results obtained at given dabigatran concentrations for ex vivo data. Thus, although PT and aPTT assays are useful for identifying potential presence of dabigatran drug effect, a normal result for either would not always exclude drug presence. In contrast, excluding occasional technical anomalies, a normal TT would exclude the presence of dabigatran, since this assay is very sensitive to its presence. This is summarized in -Table $\mathbf{1}$ and -Fig. $\mathbf{3}$.

The Hemoclot thrombin inhibitor (HTI) assay (HYPHEN BioMed, Andresy, France), dTT methods, and ECT/ECA methods all showed good sensitivity and were generally reported as useful assays for measuring levels of dabigatran. ${ }^{15-17,19-21,24,26,27,29-31,34-37,41-47}$ The PICT assay was also reported as sensitive, although this assay may require some optimization. ${ }^{20,34,35}$

Many hemostasis assays are also affected by dabigatran. All clot-based factor assays are affected by dabigatran, although aPTT-based assays (FVIII, FIX, FXI, and FXII) are most affected. $22,41,48,49$ The clot-based PC and PS assays may also be affected, but chromogenic PC and antigen-based (e.g., latexbased free) PS assays are not. ${ }^{22,41}$ AT assays are affected if they are anti-Ila based, but not if they are anti-Xa based. ${ }^{22,41}$ The APCR assays are affected, as are lupus anticoagulant (LA) assays, and false identification of associated defects are possible. ${ }^{4,18,22,40,41,49}$ On the contrary, due to its sensitivity, the dRVVT may alternatively be used to screen for the presence of dabigatran. The TEG/ROTEM-based assays are also affected, as are TGA and ACT. ${ }^{17,19,21,24,26,30,31,36,50-53}$ The VWF and platelet function tests (platelet function analyzer [PFA], Multiplate, Roche, Basel, Switzerland and light transmission aggregometry [LTA]) are not affected, except for thrombin-mediated effects. 22,31

The overall conclusion from these studies in regard to assessing drug effects is that the aPTT can be used for urgent assessment of the presence of dabigatran, although a normal aPTT will not always exclude the presence of the drug. The standard TT is most useful to screen for absence of dabigatran (= normal TT) or potential presence of dabigatran (raised TT), but it is not otherwise useful for assessment of dabigatran level because it is too sensitive. The dRVVT, using a "confirm" LA reagent, also shows good sensitivity to dabigatran and has been proposed a useful screen by some workers, including us. ${ }^{4}$ HTI/dTT and ECT/ECA assays can be used for a more accurate estimation of the anticoagulant effect of the drug and to "quantify" drug level, ${ }^{15-17,19-21,24,26,27,29-31,34-37,41-47}$ although the former tests (HTI/dTT) appear overall better standardized for this purpose than the latter (ECT/ECA).

\section{Rivaroxaban}

A similar exploration has been undertaken for rivaroxaban with a similar number of publications $(n=64)$. In contrast to dabigatran, the PT is more generally sensitive to rivaroxaban than the aPTT, although differential reagent sensitivity is observed. ${ }^{4,19,24,25,54-69}$ All TT and ecarin-based assays (i.e., standard TT, dTT, HTI, ECT, and ECA) are insensitive to rivaroxaban. ${ }^{24,35,55,61,63}$ The PICT assay was also reported as sensitive, although this assay may require some major degree of optimization. ${ }^{35,56,61,70,71}$ In general, most publications recommended the use of an anti-Xa assay using a specific rivaroxaban standard, as these assays showed greatest utility. ${ }^{55-57,61,62,64,65,68,69,72-80}$

Many hemostasis assays are also affected by rivaroxaban. All clot-based factor assays are affected by rivaroxaban, as are the clot-based PC and PS assays. ${ }^{55,64,72}$ Like dabigatran, chromogenic PC and antigen-based (e.g., latex-based free) PS assays are not. ${ }^{55,72}$ Unlike dabigatran, AT assays are affected if they are anti-Xa based, but not if they are antiIla based. ${ }^{55,60,72}$ The APCR assays are affected, as are LA assays, and false identification of associated defects is possible. ${ }^{4,40,49,60,63,73,74}$ Again, because the dRVVT is sensitive to rivaroxaban, it may be a useful screen for the presence of drug. TEG/ROTEM-based assays are also affected, as are TGA and ACT. ${ }^{19,24,30,31,53,56,57,61,65,68,81-85}$ VWF and platelet function tests (PFA, Multiplate, and LTA) are not affected. ${ }^{31}$ This is summarized in - Table $\mathbf{1}$ and -Fig. $\mathbf{3}$.

The overall conclusion from these studies in regard to assessing drug effects is that the PT can be used for urgent assessment of the presence of rivaroxaban, although a normal PT will not always exclude its presence. Consensus has also been reached that PT results should be reported as "ratio," since the use of INR may be misleading in this setting. The 
Table 1 Summary of NOAC effects on hemostasis assays

\begin{tabular}{|c|c|c|c|c|}
\hline Tests & Dabigatran & Rivaroxaban & Apixaban & Comments \\
\hline \multicolumn{5}{|c|}{ (A) Routine assays (screening) } \\
\hline PT & $-/ \uparrow$ & $\uparrow / \uparrow \uparrow$ & $-/ \uparrow$ & $\begin{array}{l}\text { Different reagents show different sensitivities; in general, } \\
\text { order of sensitivity = rivaroxaban, dabigatran, apixaban; } \\
\text { only a few reagents sensitive to apixaban }\end{array}$ \\
\hline APTT & $\uparrow / \uparrow \uparrow$ & $-/ \uparrow$ & $-/ \uparrow$ & $\begin{array}{l}\text { Different reagents show different sensitivities; in general, } \\
\text { order of sensitivity = dabigatran, rivaroxaban, apixaban }\end{array}$ \\
\hline TT & $\overline{\uparrow \uparrow \uparrow}$ & - & - & Very sensitive to dabigatran; insensitive to anti-Xa agents \\
\hline Fibrinogen & $-\mid \downarrow$ & $-\mid \downarrow$ & $-/ \downarrow$ & $\begin{array}{l}\text { Most von Clauss methods insensitive; occasional von Clauss } \\
\text { methods and PT-based methods will show some false loss }\end{array}$ \\
\hline dRVVT & $\uparrow \uparrow$ & $\uparrow \uparrow \uparrow$ & $\overline{\uparrow \uparrow}$ & Most dRVVT methods sensitive to all agents \\
\hline \multicolumn{5}{|c|}{ (B) Quantifying assays (measuring) } \\
\hline $\mathrm{dTT} / \mathrm{DTI}$ & $\uparrow \uparrow$ & - & - & $\begin{array}{l}\text { Very sensitive to dabigatran; not affected by anti-Xa agents } \\
\text { including rivaroxaban and apixaban }\end{array}$ \\
\hline $\mathrm{ECT} / \mathrm{ECA}$ & $\overline{\uparrow \uparrow}$ & - & - & $\begin{array}{l}\text { Very sensitive to dabigatran; not affected by anti-Xa agents } \\
\text { including rivaroxaban and apixaban }\end{array}$ \\
\hline $\mathrm{PICT}$ & $\overline{\uparrow \uparrow}$ & $\uparrow \uparrow$ & $\uparrow \uparrow$ & $\begin{array}{l}\text { Requires assay modifications to provide sensitivity to all agents; } \\
\text { may require different setups for anti-lla vs. anti-Xa drugs }\end{array}$ \\
\hline Anti-Xa & - & $\uparrow \uparrow$ & $\uparrow \uparrow$ & $\begin{array}{l}\text { Sensitive to anti-Xa agents (including rivaroxaban and apixaban); } \\
\text { insensitive to dabigatran }\end{array}$ \\
\hline \multicolumn{5}{|c|}{ (C) Drug interference } \\
\hline PT factors & $\downarrow / \downarrow \downarrow$ & $\downarrow / \downarrow \downarrow$ & $\downarrow / \downarrow \downarrow$ & $\begin{array}{l}\text { All PT factors affected, although most sensitive to dabigatran } \\
\text { and rivaroxaban; can also yield impression of factor inhibitor }\end{array}$ \\
\hline APTT factors & $\downarrow \downarrow / \downarrow \downarrow \downarrow$ & $\downarrow / \downarrow \downarrow$ & $\downarrow / \downarrow \downarrow$ & $\begin{array}{l}\text { All APTT factors affected, although most sensitive to dabigatran } \\
\text { and then rivaroxaban; can also yield impression of factor inhibitor }\end{array}$ \\
\hline Protein C & $-/ \uparrow$ & $-/ \uparrow$ & $-/ \uparrow$ & Chromogenic tests unaffected; clot-based tests may be affected \\
\hline Protein S & $-/ \uparrow$ & $-/ \uparrow$ & $-/ \uparrow$ & $\begin{array}{l}\text { Antigen-based tests (e.g., LIA) unaffected; clot-based } \\
\text { tests affected }\end{array}$ \\
\hline Antithrombin & $-/ \uparrow$ & $-/ \uparrow$ & $-/ \uparrow$ & $\begin{array}{l}\text { Anti-lla-based methods affected by dabigatran; anti-Xa-based } \\
\text { methods affected by other drugs }\end{array}$ \\
\hline APCR & $-/ \uparrow$ & $-/ \uparrow$ & $-/ \uparrow$ & APTT-based assays are mostly affected \\
\hline LA & $\uparrow / \uparrow \uparrow$ & $\uparrow / \uparrow \uparrow$ & $-/ \uparrow$ & $\begin{array}{l}\text { LA tests are sometimes affected so that prolongation in screen } \\
\text { assays exceed prolongation in confirm assays, leading to high } \\
\text { screen/confirm assay ratios, and thus false determination of LA. } \\
\text { This is especially true of dabigatran and rivaroxaban }\end{array}$ \\
\hline VWF & - & - & - & \\
\hline TEG & $\downarrow / \downarrow \downarrow$ & $\downarrow / \downarrow \downarrow$ & $\downarrow / \downarrow \downarrow$ & Various parameters affected \\
\hline LTA & $-^{a}$ & - & - & \\
\hline PFA & - & - & - & \\
\hline TGA & $\downarrow / \downarrow \downarrow$ & $\downarrow / \downarrow \downarrow$ & $\downarrow / \downarrow \downarrow$ & Various parameters affected \\
\hline \multicolumn{5}{|l|}{ (D) Other } \\
\hline $\mathrm{mPT} / \mathrm{dPT}$ & $\uparrow / \uparrow \uparrow$ & $\uparrow / \uparrow \uparrow$ & $\uparrow / \uparrow \uparrow$ & $\begin{array}{l}\text { Various modifications of the PT may increase sensitivity to } \\
\text { all drugs }\end{array}$ \\
\hline ACT & $\uparrow / \uparrow \uparrow$ & $-/ \uparrow$ & $-/ \uparrow$ & \\
\hline
\end{tabular}

Abbreviations: ACT, activated clotting time; APCR, activated protein C resistance; APTT, activated partial thromboplastin assay; dPT, dilute prothrombin time; dRVVT, dilute Russell viper venom time; DTI, direct thrombin inhibitor (assay); dTT, dilute thrombin time; ECA, ecarin chromogenic assay; ECT, ecarin clotting time; LA, lupus anticoagulant; LTA, light transmission aggregometry; mPT, modified prothrombin time; PFA, platelet function analyzer; PICT, prothrombinase-induced clotting time; PT, prothrombin time; TEG, thromboelastography; TGA, thrombin generation assay; TT, thrombin time; VWF, von Willebrand factor.

${ }^{a}$ Dabigatran may affect thrombin-induced aggregation. 


\begin{tabular}{|c|c|c|c|}
\hline 'Subtherapeutic' & $\begin{array}{l}\text { 'Low } \\
\text { Therapeutic' } \\
\text { (trough) }\end{array}$ & $\begin{array}{l}\text { 'High } \\
\text { Therapeutic' } \\
\text { (peak) }\end{array}$ & $\begin{array}{l}\text { 'Supra } \\
\text { Therapeutic' }\end{array}$ \\
\hline & \multicolumn{2}{|c|}{ dabigatran } & \\
\hline \multicolumn{2}{|c|}{ 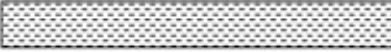 } & & PT \\
\hline \multicolumn{2}{|c|}{ 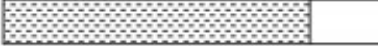 } & & APTT \\
\hline \multicolumn{4}{|l|}{ TT } \\
\hline \multicolumn{3}{|c|}{ 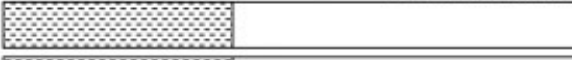 } & ECT/ECA \\
\hline \multicolumn{3}{|c|}{ 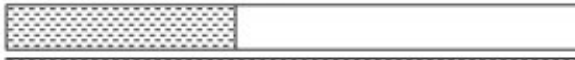 } & dTT/DTI \\
\hline \multicolumn{4}{|l|}{ Antixarasay } \\
\hline \multicolumn{3}{|c|}{ 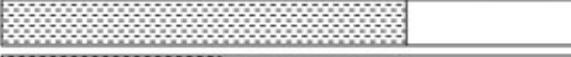 } & ACT \\
\hline \multicolumn{3}{|c|}{ 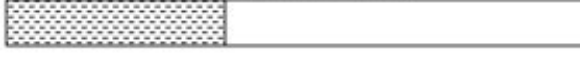 } & dRRVT \\
\hline
\end{tabular}
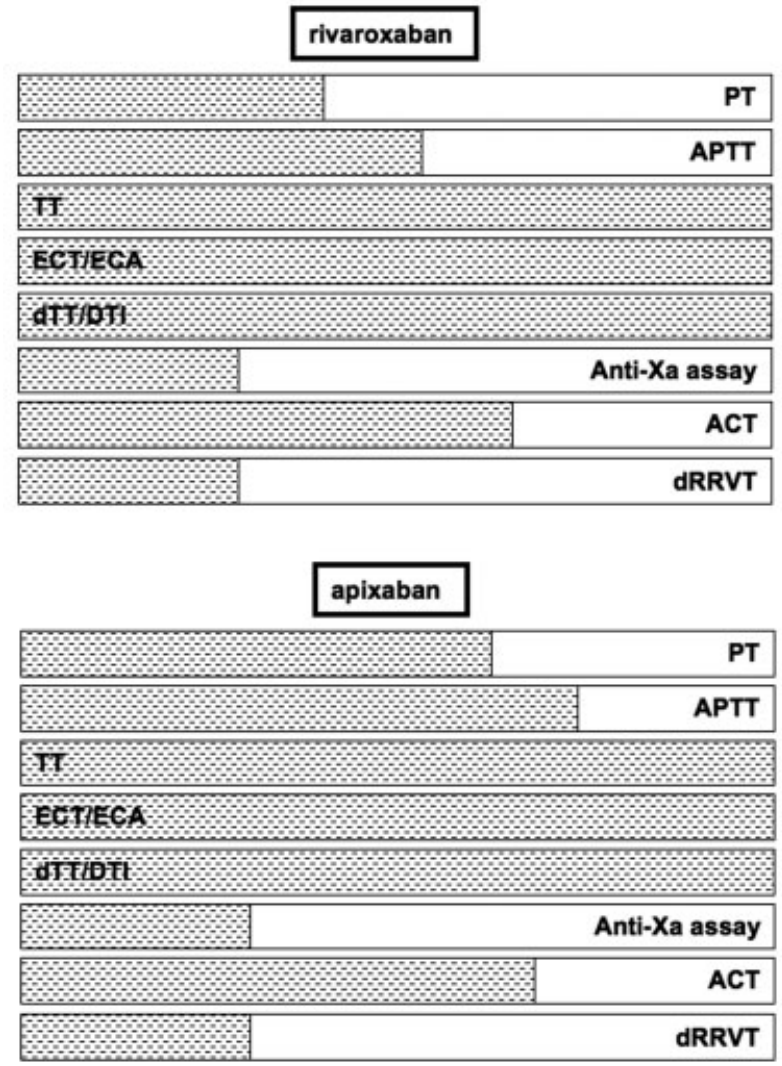

Comments

\section{Variable reagent sensitivity evident}

\section{Standardisation not yet} achieved

\section{This assay unaffected by dabigatran}

\section{Variable reagent sensitivity evident}

\section{These assays} unaffected by rivaroxaban

\section{Variable reagent sensitivity evident; most reagents} 'insensitive'

\section{These assays unaffected by} apixaban

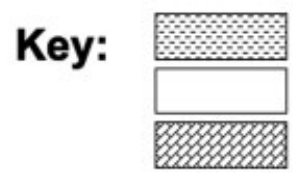

\section{Unaffected or normal result measurable result \\ Non linear or unmeasurable result}

Fig. 3 Potential "clinical utility" of different laboratory tests to assess the main three NOACs (dabigatran, rivaroxaban, and apixaban) shown by relative sensitivity to each drug at "subtherapeutic," "therapeutic," and "supratherapeutic" levels. These concepts are a little abstract, as "therapeutic ranges" for these NOAC do not exist; however, based on samples taken from patients at "trough" versus "peak" times, postdosing existing data provide an approximate "therapeutic range" for each NOAC (see Lippi and Favaloro). ${ }^{4}$ Figure represents a modification and expansion of the concept from Hawes et al. ${ }^{26}$ ACT, activated clotting time; APTT, activated partial thromboplastin time; dRVVT, dilute Russell viper venom time; DTI, direct thrombin inhibitor (assay); dTT, dilute thrombin time; ECT, ecarin clotting time; ECA, ecarin chromogenic assay; PT, prothrombin time; TT, thrombin time. 
dRVVT, using a "confirm" LA reagent, has also been proposed as a useful screen by some workers, including us, because it also shows good sensitivity to rivaroxaban. ${ }^{4}$ However, an anti-Xa assay, using a specific rivaroxaban standard, is most useful to measure drug levels.

\section{Apixaban}

A similar but less extensive exploration has been undertaken for apixaban with a smaller number of publications $(n=26)$. Apixaban shows least sensitivity of the three main NOACs to routine tests, and most PT and aPTT reagents only show mild sensitivity. ${ }^{4,55,86-94}$ However, some variability is evident and some reagents appear to be sensitive, although most are not. Like rivaroxaban, all TT and ecarin-based assays are insensitive to apixaban, and although the PICT assay was also reported as sensitive, this assay may require some optimization. ${ }^{35,55,88,91}$ In general, most publications recommended the anti-Xa assay using a specific apixaban standard, as these assays showed greatest efficacy. ${ }^{55,86-92,95-98}$

Many hemostasis assays are also affected by apixaban, although less so than by rivaroxaban. The clot-based factor assays are mildly affected by apixaban, ${ }^{55,88,91}$ so that levels often (but not always) remain in the normal range. Similarly, clot-based PC and PS assays may also be affected, but like the other NOACs, chromogenic PC and antigen-based (e.g., latexbased free) PS assays are not. ${ }^{55,88,91}$ Like rivaroxaban, AT assays are affected by apixaban if they are anti-Xa based, but not if they are anti-Ila based. ${ }^{55,88,91}$ The APCR and LA assays may also be affected by apixaban, and false identification of associated defects are possible, but less likely than for rivaroxaban. 4,49,55,88,90,92 Again, because the dRVVT is sensitive to apixaban, it may be a useful screen for the presence of drug. The TEG/ROTEM-based assays are also affected by apixaban, as are TGA and ACT. ${ }^{32,55,81,88}$ The VWF and platelet function tests (PFA, Multiplate, and LTA) are not affected. ${ }^{31}$ This is summarized in - Table $\mathbf{1}$ and - Fig. 3.

The overall conclusion from these studies in regard to assessing drug effects is that the routine coagulation tests (both PT and aPTT) cannot be used for urgent assessment of the presence of apixaban, since normal results will not exclude its presence. However, a study from the Subcommittee on Control of Anticoagulation of the International Society of Thrombosis and Haemostasis has recently concluded that standardization of sensitive PT assays produced results that were comparable with most chromogenic anti-FXa assays. This represents a reasonable background for further studies aimed at establishing whether PT may also be used as a firstline test for screening apixaban concentration..$^{91}$ The dRVVT, using a "confirm" LA reagent, has also been proposed as a useful screen by some workers, including us, because it also shows good sensitivity to apixaban. ${ }^{4}$ However, an anti-Xa assay, using a specific apixaban standard, is most useful to accurately measure drug levels.

\section{Other NOACs}

At variance with the three main NOACs, information on routine or urgent assessment of the other NOACs is scarce, although PT, aPTT, and anti-FXa activity have all been reported to be prolonged by edoxaban. ${ }^{99}$ However, data to date suggest that the anti-FXa assay may be most suited for its assessment, albeit potentially requiring modification to optimize the assay.

\section{A Practical Approach to Laboratory Assessment of NOACs}

Given the background data, and our own experience with these agents, our recommended approach is similar to that we recently published, and in line with most other major expert recommendations. ${ }^{4}$

As regard to dabigatran and other potential FIIa direct oral inhibitors, the aPTT is generally a reliable screening test in patients taking this drug, especially when rapid and reliable information about the potential risk of overcoagulation is needed. The standard TT is also useful for exclusion of dabigatran (normal TT). The dRVVT is also a useful screening test. However, for an accurate estimation of the anticoagulant effect, the HTI or dTT (or ECT/ECA where this assay is available and has been optimized) is recommended.

As regard to anti-FXa inhibitors, the PT would represent a reliable screening test in patients taking rivaroxaban, especially when rapid and reliable information about the potential risk of overcoagulation is needed, but with some notable exceptions related to reagent sensitivity. The PT is generally not recommended for screening of patients taking apixaban due to poorer sensitivity. However, sensitive PT reagents are available and can be used for this purpose. ${ }^{91}$ The dRVVT is a useful screening test for both rivaroxaban and apixaban. However, for a more accurate estimation of the anticoagulant effect of anti-FXa inhibitors, specific antiFXa assays (using the specific drug as calibrator) are the preferred means.

Taken together, the available published evidence allows the development of tentative algorithms for urgent and routine measurement of NOACs (-Fig. 4). Before embarking on routine or specialized testing of the NOACs, all laboratories must assess, and if required optimize, all assays for such use (-Fig. 4A). All test results must also be considered in light of respective assay sensitivities and with respect to timing of last dose of NOAC (-Fig. 4A).

When urgent screening of NOACs are required and when the drug being assessed is known, a simplified testing approach is reasonable and may entail the use of aPTT for dabigatran (and other anti-FIla inhibitors) and PT for rivaroxaban (-Fig. 4B), for screening purposes. Where available, the dRVVT may also be useful to screen for these NOACs. No conventional clotting test seems generally suitable for apixaban and edoxaban, although the dRVVT appears to be an acceptable option (at least for apixaban), and ongoing studies will confirm the reliability of using sensitive PTs for the screening of apixaban anticoagulant activity. As regard to the accurate estimation of the anticoagulant effect, this may be accomplished for dabigatran with DTI/HTI/ dTT (or a suitable ECT/ECA) and for all anti-FXa drugs with antiFXa assays, using specific calibrators, with some residual doubts about the effectiveness of these tests for measuring the anticoagulant effect of edoxaban. 


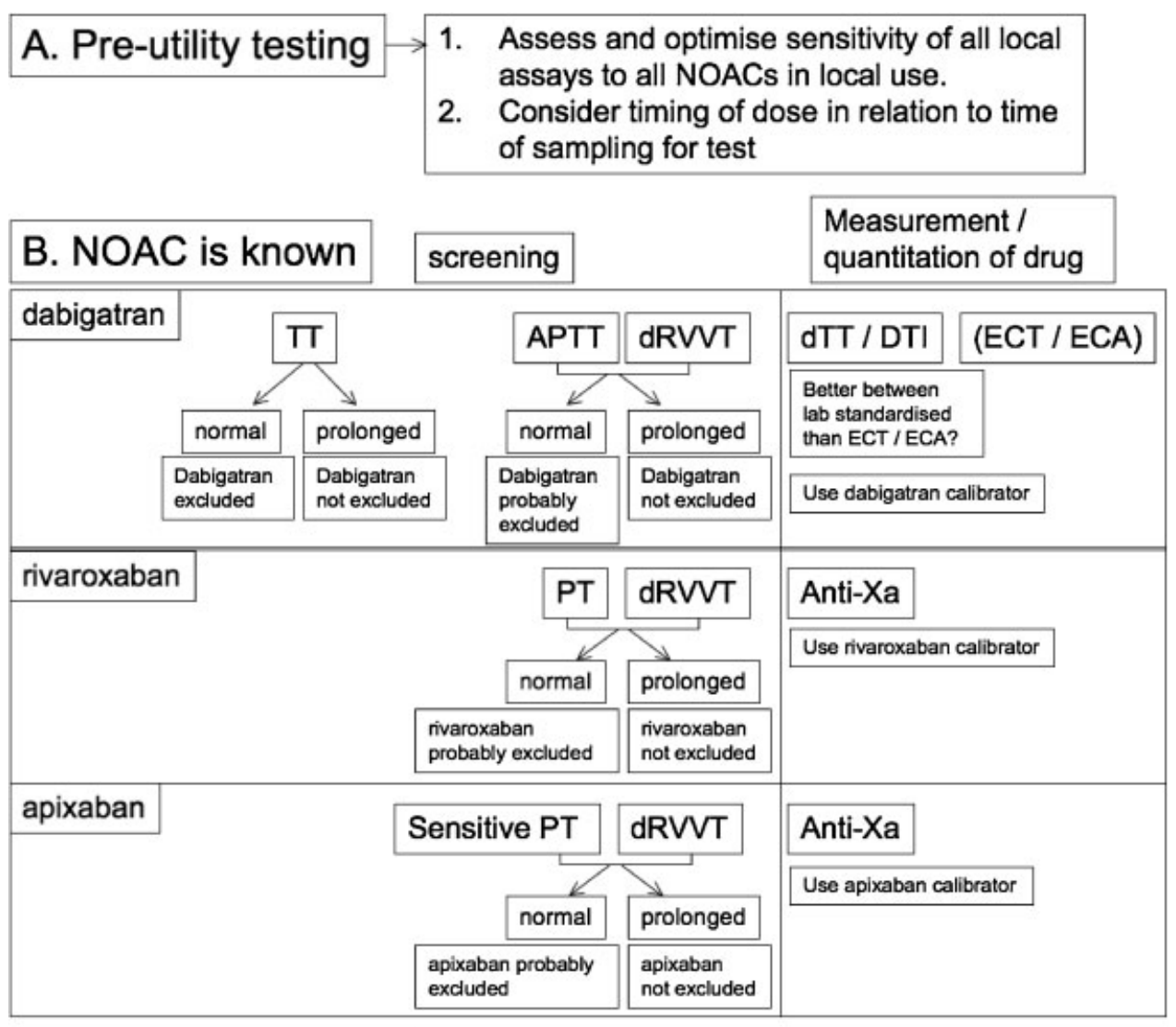

\section{NOAC is unknown}

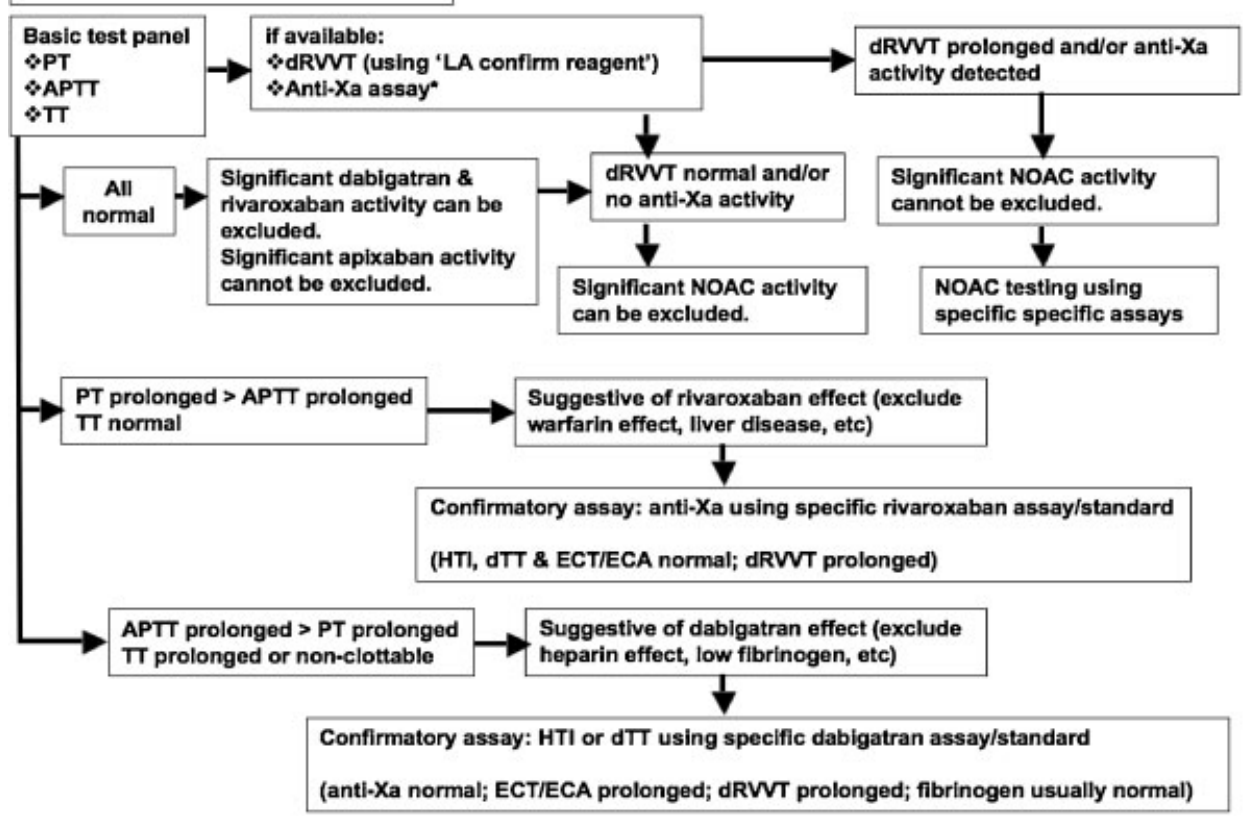

Fig. 4 Proposed approach/algorithms to hemostasis investigation of patients on NOACs. (A) Requirements before initiating clinical testing. (B) Suggested test approach for the urgent screening of dabigatran, rivaroxaban, and apixaban, when the drug being assessed is known. (C) Suggested test approach for the urgent screening of dabigatran, rivaroxaban, and apixaban, when the drug being assessed is not known. Refer to text for further explanation. Modified from Lippi and Favaloro. ${ }^{4}$ aPTT, activated partial thromboplastin time; dRVVT, dilute Russell viper venom time; DTI, direct thrombin inhibitor (assay); dTT, dilute thrombin time; ECT, ecarin clotting time; ECA, ecarin chromogenic assay; PT, prothrombin time; TT, thrombin time. 
When urgent screening of NOACs is required and when the drug being assessed is not known, a more complex or

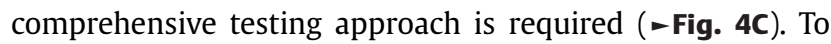
some extent, the approach undertaken depends on tests available at local sites. All coagulation laboratories tend to perform PT and aPTT assays, with these typically available 24 hours/day. Many laboratories can also perform TT assays. Accordingly, these assays are recommended as a preliminary screen, and normal results will provide sufficient evidence for excluding significant effects from dabigatran and rivaroxaban (assuming the laboratory has validated relative sensitivities to these drugs). Normal PT and aPTT assays may not discount an apixaban (or edoxaban) effect, due to low sensitivity. The dRVVT assays are also often available in many coagulation laboratories, being used for LA testing. In our experience, this assay, using the confirmation regent to reduce possible LA interference, can provide additional information, and a normal dRVVT can be used to exclude a significant dabigatran, rivaroxaban, and apixaban effect. The pattern of results from these four clot-based assays, readily available in many coagulation laboratories, can also inform on the possible drug present ( $\boldsymbol{\sim}$ Tables 1 and 2), given that each drug provides a different pattern.

An anti-Xa assay can also be performed. In a preliminary screen approach, any anti-Xa assay will do, providing the laboratory recognizes the sensitivity of this assay for the different NOACs. For example, even a "standard" anti-Xa assay using a LMWH heparin standard will provide some information, with no activity discounting all anti-Xa NOACs (as well as UFH and LMWH), and low levels suggesting some anti-Xa NOAC (or UFH/LMWH) activity, and high levels suggesting a greater potential anti-Xa NOAC/UFH/LMWH influence. Naturally, if the specific assays are available, and should drug levels require quantification, then specific quantitative assays should instead, or additionally, be performed ( - Fig. 4C). Indeed, the use of the panel of assays shown here will also help determine the likely drug, given the different patterns observed ( - Table 1 ). Indeed, the test patterns for the NOACs are also different to those of classical anticoagulants (VKAs/ UFH/LMWH) (-Table 2), so a particular test pattern for an unknown drug can likely inform on the identity of that drug.
In regard to recent local (Australasian) experience, the DTI/ dTT assays have been found to be much more sensitive to dabigatran, and more reproducible in this setting than existing ECT/ECA assays in use. ${ }^{41}$ In addition, data from the commercial DTI (HTI) and in-house dTT assays were almost interchangeable. ${ }^{41}$ Based on these data, we would currently recommend the DTI/dTT method(s) ahead of the ECT/ECA methods for assessment of dabigatran. However, better harmonization of the ECT/ECA assays in other localities may provide additional support for use of these assays in place of DTI/dTT assays in those geographies. Moreover, in some countries, the ECT/ECA assays may be cleared by regulators of in vitro diagnostic products, but DTI/dTT assays may not be. We have previously reported on differential geographical hemostasis testing based on regulatory issues. ${ }^{100}$

In regard to PICT assays, although these have been shown sensitive to most NOACs, they may require some further degree of optimization, and perhaps separate methodological assays for anti-IIa and anti-Xa NOAC agents. $., 20,34,35,56,61,70,71,91$

\section{Assay Interferences}

In regard to assay interferences, all NOACs affect most clotbased assays, and anti-Ila agents and anti-Xa agents will also, respectively, affect assays based on anti-IIa and anti-Xa activity (e.g., AT). ${ }^{18,22,41,49,55,60,63,72-74,88,90,92,101}$ In general, LA testing should be avoided while patients are on NOAC therapy. In particular, testing for $L A$ while patients are treated with dabigatran or rivaroxaban will provide false-positive LA results on most samples, with prolongation in LA screening assays often yielding higher values than prolonged confirm assays, with resultant high test screen/confirm ratios. $^{4,22,41,49,55,63,73,74,88,90,92}$ Although apixaban is less likely to yield a false-positive LA, prolonging screen and confirm LA assays more concordantly, it may be safer to avoid LA testing also in these patients. Factor assay testing should also be avoided while patients are on NOAC therapy, with dabigatran and rivaroxaban in particular affecting all clotting factors and potentially yielding false-low values. Again, although apixaban is less likely to yield a false-low factor

Table 2 Summary of test patterns for NOACs and conventional anticoagulants

\begin{tabular}{|l|l|l|l|l|l|l|}
\hline \multirow{2}{*}{ Coagulation test } & \multicolumn{5}{l}{ Effect of } \\
\cline { 2 - 8 } & $\begin{array}{l}\text { Anti-Ila NOAC } \\
\text { dabigatran }\end{array}$ & $\begin{array}{l}\text { Anti-Xa NOAC } \\
\text { rivaroxaban }\end{array}$ & $\begin{array}{l}\text { Anti-Xa NOAC } \\
\text { apixaban }\end{array}$ & VKAs & UH & LMWH \\
\hline PT/INR & + & ++ & $(+)$ & ++ & $-l+$ & - \\
\hline aPTT & ++ & + & $(+)$ & + & ++ & $-/+$ \\
\hline TT & ++ & - & - & - & ++ & $+/-$ \\
\hline Anti-Xa & - & ++ & ++ & - & ++ & ++ \\
\hline dRVVT & ++ & ++ & ++ & ++ & $-/++$ & - \\
\hline
\end{tabular}

Abbreviations: APTT, activated partial thromboplastin time; dRVVT, dilute Russell viper venom time; INR, International Normalized Ratio; LMWH, lowmolecular-weight heparin; NOAC, non-vitamin K antagonist oral anticoagulant; PT, prothrombin time; TT, thrombin time; UH, unfractionated heparin; VKAs, vitamin $\mathrm{K}$ antagonists.

Note: UH at therapeutic levels will not affect PT or dRVVT when these reagents contain a heparin neutralizer; however, excess UH will affect these assays when neutralizer limits are exceeded.

Source: Modified from Lippi and Favaloro. ${ }^{4}$ 
level, it may also be safer to avoid factor testing in these patients. The clot-based PC and PS assays should also be avoided on patients on any NOAC; however, chromogenic PC and antigenic PS assays seem to be unaffected. AT assays are affected by the NOACs, with anti-Ila-based assays affected by dabigatran and anti-Xa assays affected by the anti-Xa agents. If AT testing is required, the alternative assays will need to be employed to obtain an accurate test result. The APCR assays should also be avoided on patients on NOAC treatment. In general, platelet function and VWF tests (excluding FVIII) are unaffected by the NOACs, as these are not clot based. Finally, TEG/ROTEM and TGA are affected and should also be avoided, except, of course, if drug effects are specifically being assessed.

\section{Reversal of NOACs}

As mentioned early in this review, an increasing number of studies have reported on reversal on NOACs using many laboratory assays. As also noted earlier, a full discussion on these studies would require another separate review. However, a brief overview is important for completeness. In general, there are no specific antidotes currently available, although a few are in clinical trials. ${ }^{102}$ Accordingly, most studies to date have reported on several currently available prothrombin complex concentrates or "bypassing" agents (including factor eight inhibitor bypass activity) and activated FVIIa). ${ }^{30,36,50,51,82,83,103-112}$ of interest, all agents have been shown to correct some but not all hemostasis tests. In general, these agents do not "correct" the specific activity. Therefore, reversal agents, in general, do not correct TT/dTT/DTI for dabigatran, nor do they correct anti-Xa assays for anti-Xa agents. Most studies have instead employed global assays such as PT, aPTT, TEG/ROTEM, and TGA, and many parameters within TEG/ROTEM and TGA are "corrected," at least partially, by most agents. Whether this will translate to effective treatments for bleeding, or whether the specific antidotes in development will abrogate their need in some cases, will need to await future evaluation.

\section{Conclusion}

The development and marketing of NOACs has revolutionized the historical approach to anticoagulant therapy. ${ }^{113,114}$ Although these novel classes of agents present several advantages over traditional VKAs and heparins, the claimed benefit that laboratory monitoring is not needed cannot be taken to mean that measurement of their effect will never be required. There are several situations in which routine and urgent measurement of NOACs is required, with these likely to further increase as NOACs continue to replace conventional anticoagulants for increasing numbers of indications in increasing numbers of patients. In a world with limited resources, the use of simple and economical means for therapeutic drug assessments represents the most logical approach ( - Fig. 4), provided that the sensitivity of all tests to all NOACs are known, and if required optimized, and providing time of last dose is taken into account.
The dRVVT remains an underappreciated test for its potential contribution to laboratory assessment of NOACs. In many cases, the sensitivity of the dRVVT is higher than that for the routine assays (PT and aPTT). As the dRVVT is used widely in LA detection, it should not be difficult for laboratories to assess the sensitivity of the reagent in use in their laboratory against the DOACs. ${ }^{4,8,41,49,55,63}$ Again, given potential variable sensitivities evident against the different NOACs with different dRVVT reagents, laboratories will need to properly evaluate the dRVVT assay in use in their laboratory against all the NOACs in use in their locality.

Finally, of additional interest, it can be noted that the NOACs can be assessed in nonplasma samples and by POC test methods. Thus, Harenberg et al have extensively shown that the measurement of dabigatran, rivaroxaban, and apixaban is feasible in serum samples of patients, and reliable at least for the latter two agents, and is also possible in urine..$^{9,115-119}$ These may provide additional opportunities when plasma samples are unavailable, and where additional plasma collection is impractical or not possible.

\section{References}

1 Guyatt GH, Akl EA, Crowther M, Gutterman DD, Schuünemann HJ; American College of Chest Physicians Antithrombotic Therapy and Prevention of Thrombosis Panel. Executive summary: Antithrombotic Therapy and Prevention of Thrombosis, 9th ed: American College of Chest Physicians Evidence-Based Clinical Practice Guidelines. Chest 2012;141(2 Suppl):7S-47S

2 Lippi G, Franchini M, Favaloro EJ. Pharmacogenetics of vitamin K antagonists: useful or hype? Clin Chem Lab Med 2009;47(5): 503-515

3 Favaloro EJ, Lippi G, Koutts J. Laboratory testing of anticoagulants: the present and the future. Pathology 2011;43(7):682-692

4 Lippi G, Favaloro EJ. Recent guidelines and recommendations for laboratory assessment of the direct oral anticoagulants (DOACs): is there consensus? Clin Chem Lab Med 2015;53(2):185-197

5 Husted S, de Caterina R, Andreotti F, et al; ESC Working Group on Thrombosis Task Force on Anticoagulants in Heart Disease. Nonvitamin K antagonist oral anticoagulants (NOACs): No longer new or novel. Thromb Haemost 2014;111(5):781-782

6 Ruff CT, Giugliano RP, Braunwald E, et al. Comparison of the efficacy and safety of new oral anticoagulants with warfarin in patients with atrial fibrillation: a meta-analysis of randomised trials. Lancet 2014;383(9921):955-962

7 McMahon BJ, Kwaan HC. The new or non-vitamin K antagonist oral anticoagulants: what have we learned since their debut. Semin Thromb Hemost 2015;41(2):188-194

8 Favaloro EJ, Lippi G. The new oral anticoagulants and the future of haemostasis laboratory testing. Biochem Med (Zagreb) 2012; 22(3):329-341

9 Harenberg J, Du S, Krämer S, Weiss C, Krämer R, Wehling M. Patients' serum and urine as easily accessible samples for the measurement of non-vitamin $\mathrm{K}$ antagonist oral anticoagulants. Semin Thromb Hemost 2015;41(2):228-236

10 Zolfaghari S, Harenberg J, Frölich L, et al. Development of recommendations to continue anticoagulation with one of the two types of oral anticoagulants based on the identification of patients' preference. Semin Thromb Hemost 2015;41(2): 166-177

11 van der Hulle T, Kooiman J, den Exter PL, Dekkers OM, Klok FA, Huisman MV. Effectiveness and safety of novel oral anticoagulants as compared with vitamin K antagonists in the treatment of 
acute symptomatic venous thromboembolism: a systematic review and meta-analysis. J Thromb Haemost 2014;12(3):320-328

12 Loke YK, Pradhan S, Yeong JK, Kwok CS. Comparative coronary risks of apixaban, rivaroxaban and dabigatran: a meta-analysis and adjusted indirect comparison. Br J Clin Pharmacol 2014; 78(4):707-717

13 Lippi G, Favaloro EJ, Mattiuzzi C. Combined administration of antibiotics and direct oral anticoagulants: a renewed indication for laboratory monitoring? Semin Thromb Hemost 2014;40(7): 756-765

14 Gous T, Couchman L, Patel JP, Paradzai C, Arya R, Flanagan RJ. Measurement of the direct oral anticoagulants apixaban, dabigatran, edoxaban, and rivaroxaban in human plasma using turbulent flow liquid chromatography with high-resolution mass spectrometry. Ther Drug Monit 2014;36(5):597-605

15 Stangier J, Rathgen K, Stähle H, Gansser D, Roth W. The pharmacokinetics, pharmacodynamics and tolerability of dabigatran etexilate, a new oral direct thrombin inhibitor, in healthy male subjects. Br J Clin Pharmacol 2007;64(3):292-303

16 Stangier J, Stähle H, Rathgen K, Fuhr R. Pharmacokinetics and pharmacodynamics of the direct oral thrombin inhibitor dabigatran in healthy elderly subjects. Clin Pharmacokinet 2008;47(1): 47-59

17 van Ryn J, Stangier J, Haertter S, et al. Dabigatran etexilate-a novel, reversible, oral direct thrombin inhibitor: interpretation of coagulation assays and reversal of anticoagulant activity. Thromb Haemost 2010;103(6):1116-1127

18 Lindahl TL, Baghaei F, Blixter IF, et al; Expert Group on Coagulation of the External Quality Assurance in Laboratory Medicine in Sweden. Effects of the oral, direct thrombin inhibitor dabigatran on five common coagulation assays. Thromb Haemost 2011; 105(2):371-378

19 Freyburger G, Macouillard G, Labrouche S, Sztark F. Coagulation parameters in patients receiving dabigatran etexilate or rivaroxaban: two observational studies in patients undergoing total hip or total knee replacement. Thromb Res 2011;127(5):457-465

20 Harenberg J, Giese C, Marx S, Krämer R. Determination of dabigatran in human plasma samples. Semin Thromb Hemost 2012;38(1):16-22

21 Douxfils J, Mullier F, Robert S, Chatelain C, Chatelain B, Dogné JM. Impact of dabigatran on a large panel of routine or specific coagulation assays. Laboratory recommendations for monitoring of dabigatran etexilate. Thromb Haemost 2012;107(5):985-997

22 Halbmayer WM, Weigel G, Quehenberger P, et al. Interference of the new oral anticoagulant dabigatran with frequently used coagulation tests. Clin Chem Lab Med 2012;50(9):1601-1605

23 Dager WE, Gosselin RC, Kitchen S, Dwyre D. Dabigatran effects on the international normalized ratio, activated partial thromboplastin time, thrombin time, and fibrinogen: a multicenter, in vitro study. Ann Pharmacother 2012;46(12):1627-1636

24 Samama MM, Guinet C, Le Flem L, Ninin E, Debue JM. Measurement of dabigatran and rivaroxaban in primary prevention of venous thromboembolism in 106 patients, who have undergone major orthopedic surgery: an observational study. J Thromb Thrombolysis 2013;35(2):140-146

25 Helin TA, Pakkanen A, Lassila R, Joutsi-Korhonen L. Laboratory assessment of novel oral anticoagulants: method suitability and variability between coagulation laboratories. Clin Chem 2013; 59(5):807-814

26 Hawes EM, Deal AM, Funk-Adcock D, et al. Performance of coagulation tests in patients on therapeutic doses of dabigatran: a cross-sectional pharmacodynamic study based on peak and trough plasma levels. J Thromb Haemost 2013;11(8):1493-1502

27 Douxfils J, Dogné JM, Mullier F, et al. Comparison of calibrated dilute thrombin time and aPTT tests with LC-MS/MS for the therapeutic monitoring of patients treated with dabigatran etexilate. Thromb Haemost 2013;110(3):543-549
28 Hapgood G, Butler J, Malan E, Chunilal S, Tran H. The effect of dabigatran on the activated partial thromboplastin time and thrombin time as determined by the Hemoclot thrombin inhibitor assay in patient plasma samples. Thromb Haemost 2013; 110(2):308-315

29 Antovic JP, Skeppholm M, Eintrei J, et al. Evaluation of coagulation assays versus LC-MS/MS for determinations of dabigatran concentrations in plasma. Eur J Clin Pharmacol 2013;69(11): $1875-1881$

30 Herrmann R, Thom J, Wood A, Phillips M, Muhammad S, Baker R. Thrombin generation using the calibrated automated thrombinoscope to assess reversibility of dabigatran and rivaroxaban. Thromb Haemost 2014;111(5):989-995

31 Eller T, Busse J, Dittrich M, et al. Dabigatran, rivaroxaban, apixaban, argatroban and fondaparinux and their effects on coagulation POC and platelet function tests. Clin Chem Lab Med 2014; 52(6):835-844

32 Chin PK, Wright DF, Patterson DM, Doogue MP, Begg EJ. A proposal for dose-adjustment of dabigatran etexilate in atrial fibrillation guided by thrombin time. Br J Clin Pharmacol 2014; 78(3):599-609

33 Stang L, Nahirniak S, Butcher K, Szkotak AJ. Dabigatran assessment in patients with acute complications using routine coagulation assays. Blood Coagul Fibrinolysis 2014;25(5):426-434

34 Lind SE, Boyle ME, Fisher S, Ishimoto J, Trujillo TC, Kiser TH. Comparison of the aPTT with alternative tests for monitoring direct thrombin inhibitors in patient samples. Am J Clin Pathol 2014;141(5):665-674

35 Schmitz EM, Boonen K, van den Heuvel DJ, et al. Determination of dabigatran, rivaroxaban and apixaban by ultra-performance liquid chromatography - tandem mass spectrometry (UPLCMS/MS) and coagulation assays for therapy monitoring of novel direct oral anticoagulants. J Thromb Haemost 2014;12(10): 1636-1646

36 van Ryn J, Grottke O, Spronk H. Measurement of dabigatran in standardly used clinical assays, whole blood viscoelastic coagulation, and thrombin generation assays. Clin Lab Med 2014;34(3): 479-501

37 Skeppholm M, Hjemdahl P, Antovic JP, et al. On the monitoring of dabigatran treatment in "real life" patients with atrial fibrillation. Thromb Res 2014;134(4):783-789

38 Czubek U, Góralczyk T, Zalewski J, Undas A. Monitoring of anticoagulant effects of dabigatran in everyday practice: first experience in 32 Polish patients. Pol Arch Med Wewn 2014; 124(9):487-489

39 Van Blerk M, Bailleul E, Chatelain B, et al. Influence of dabigatran and rivaroxaban on routine coagulation assays. A nationwide Belgian survey. Thromb Haemost 2015;113(1):154-164

40 Martinuzzo ME, Barrera LH, D'adamo MA, Otaso JC, Gimenez MI, Oyhamburu J. Frequent false-positive results of lupus anticoagulant tests in plasmas of patients receiving the new oral anticoagulants and enoxaparin. Int J Lab Hematol 2014;36:144-150

41 Bonar R, Favaloro EJ, Marsden K; RCPAQAP Haematology Haemostasis Committee. Dabigatran Special Exercise Report. Issued April, 2014. RCPA Quality Assurance Programs Pty Limited. St Leonards, NSW, Australia

42 Stangier J, Feuring M. Using the HEMOCLOT direct thrombin inhibitor assay to determine plasma concentrations of dabigatran. Blood Coagul Fibrinolysis 2012;23(2):138-143

43 Avecilla ST, Ferrell C, Chandler WL, Reyes M. Plasma-diluted thrombin time to measure dabigatran concentrations during dabigatran etexilate therapy. Am J Clin Pathol 2012;137(4): 572-574

44 Samoš M, Stančiaková L, Ivanková J, et al. Monitoring of dabigatran therapy using Hemoclot( $\left({ }^{\circledR}\right)$ Thrombin Inhibitor assay in patients with atrial fibrillation. J Thromb Thrombolysis 2015; 39(1):95-100 
45 Visino F, Zaccaria F, Semeraro N, Colucci M. A modified prothrombin time to measure the anticoagulant activity of dabigatran. Thromb Res 2014;134(6):1368-1369

46 Gosselin R, Hawes E, Moll S, Adcock D. Performance of various laboratory assays in the measurement of dabigatran in patients receiving therapeutic doses: a prospective study based on peak and trough plasma levels. Am J Clin Pathol 2014;141(2):262-267

47 Gosselin RC, Dwyre DM, Dager WE. Measuring dabigatran concentrations using a chromogenic ecarin clotting time assay. Ann Pharmacother 2013;47(12):1635-1640

48 Tsutsumi Y, Shimono J, Ohhigashi H, Ito S, Shiratori S, Teshima T. Analysis of the influence of dabigatran on coagulation factors and inhibitors. Int J Lab Hematol 2014; doi: 10.1111/ijlh.12270

49 Exner T, Ellwood L, Rubie J, Barancewicz A. Testing for new oral anticoagulants with LA-resistant Russells viper venom reagents. An in vitro study. Thromb Haemost 2013;109(4):762-765

50 Khoo TL, Weatherburn C, Kershaw G, Reddel CJ, Curnow J, Dunkley S. The use of FEIBA $®$ in the correction of coagulation abnormalities induced by dabigatran. Int J Lab Hematol 2013; 35(2):222-224

51 Solbeck S, Meyer MA, Johansson PI, et al. Monitoring of dabigatran anticoagulation and its reversal in vitro by thrombelastography. Int J Cardiol 2014;176(3):794-799

$52 \mathrm{Xu} \mathrm{Y,} \mathrm{Wu} \mathrm{W,} \mathrm{Wang} \mathrm{L,} \mathrm{et} \mathrm{al.} \mathrm{Differential} \mathrm{profiles} \mathrm{of} \mathrm{thrombin}$ inhibitors (heparin, hirudin, bivalirudin, and dabigatran) in the thrombin generation assay and thromboelastography in vitro. Blood Coagul Fibrinolysis 2013;24(3):332-338

53 Hosokawa K, Ohnishi T, Sameshima H, et al. Comparative evaluation of direct thrombin and factor Xa inhibitors with antiplatelet agents under flow and static conditions: an in vitro flow chamber model. PLoS ONE 2014;9(1):e86491

54 Dale BJ, Ginsberg JS, Johnston M, Hirsh J, Weitz JI, Eikelboom JW. Comparison of the effects of apixaban and rivaroxaban on prothrombin and activated partial thromboplastin times using various reagents. J Thromb Haemost 2014;12(11): $1810-1815$

55 Bonar R, Favaloro EJ, Marsden K; RCPAQAP Haematology Haemostasis Committee. Apixaban and Rivaroxaban Trial Report. Issued December, 2014. RCPA Quality Assurance Programs Pty Limited. St Leonards, NSW, Australia

56 Samama MM, Martinoli JL, LeFlem L, et al. Assessment of laboratory assays to measure rivaroxaban-an oral, direct factor Xa inhibitor. Thromb Haemost 2010;103(4):815-825

57 Francart SJ, Hawes EM, Deal AM, et al. Performance of coagulation tests in patients on therapeutic doses of rivaroxaban. A crosssectional pharmacodynamic study based on peak and trough plasma levels. Thromb Haemost 2014;111(6):1133-1140

58 Arachchillage DR, Efthymiou M, Lawrie AS, Machin SJ, Mackie IJ, Cohen H. Comparative sensitivity of commonly used thromboplastins to ex vivo therapeutic rivaroxaban levels. Thromb Haemost 2014;112(2):421-423

59 Tripodi A, Chantarangkul V, Guinet C, Samama MM. The International Normalized Ratio calibrated for rivaroxaban has the potential to normalize prothrombin time results for rivaroxabantreated patients: results of an in vitro study. J Thromb Haemost 2011;9(1):226-228

60 Hillarp A, Baghaei F, Fagerberg Blixter I, et al. Effects of the oral, direct factor Xa inhibitor rivaroxaban on commonly used coagulation assays. J Thromb Haemost 2011;9(1):133-139

61 Douxfils J, Mullier F, Loosen C, Chatelain C, Chatelain B, Dogné JM. Assessment of the impact of rivaroxaban on coagulation assays: laboratory recommendations for the monitoring of rivaroxaban and review of the literature. Thromb Res 2012; 130(6):956-966

62 Linkins LA, Moffat K. Monitoring the anticoagulant effect after a massive rivaroxaban overdose. J Thromb Haemost 2014;12(9): 1570-1571
63 Altman R, Gonzalez CD. Simple and rapid assay for effect of the new oral anticoagulant (NOAC) rivaroxaban: preliminary results support further tests with all NOACs. Thromb J 2014; $12(1): 7$

64 Asmis LM, Alberio L, Angelillo-Scherrer A, et al. Rivaroxaban: Quantification by anti-FXa assay and influence on coagulation tests: a study in 9 Swiss laboratories. Thromb Res 2012;129(4):492-498

65 Attard C, Monagle P, Kubitza D, Ignjatovic V. The in vitro anticoagulant effect of rivaroxaban in children. Thromb Res 2012; 130(5):804-807

66 Harenberg J, Marx S, Krämer R, Giese C, Weiss C. Determination of an international sensitivity index of thromboplastin reagents using a WHO thromboplastin as calibrator for plasma spiked with rivaroxaban. Blood Coagul Fibrinolysis 2011;22(8): 637-641

67 Samama MM, Contant G, SpiroTE, et al; Rivaroxaban Prothrombin Time Field Trial Laboratories. Evaluation of the prothrombin time for measuring rivaroxaban plasma concentrations using calibrators and controls: results of a multicenter field trial. Clin Appl Thromb Hemost 2012;18(2):150-158

68 Molenaar PJ, Dinkelaar J, Leyte A. Measuring Rivaroxaban in a clinical laboratory setting, using common coagulation assays, Xa inhibition and thrombin generation. Clin Chem Lab Med 2012; 50(10):1799-1807

69 Harenberg J, Erdle S, Marx S, Krämer R. Determination of rivaroxaban in human plasma samples. Semin Thromb Hemost 2012; 38(2):178-184

70 Harder S, Parisius J, Picard-Willems B. Monitoring direct FXainhibitors and fondaparinux by Prothrombinase-induced Clotting Time (PiCT): relation to FXa-activity and influence of assay modifications. Thromb Res 2008;123(2):396-403

71 Kluft C, Meijer P, Kret R, Burggraaf J. Preincubation in the Prothrombinase-induced Clotting Time test (PiCT) is necessary for in vitro evaluation of fondaparinux and to be avoided for the reversible, direct factor Xa inhibitor, rivaroxaban. Int J Lab Hematol 2013;35(4):379-384

72 Gerotziafas GT, Baccouche H, Sassi M, et al. Optimisation of the assays for the measurement of clotting factor activity in the presence of rivaroxaban. Thromb Res 2012;129(1):101-103

73 Merriman E, Kaplan Z, Butler J, Malan E, Gan E, Tran H. Rivaroxaban and false positive lupus anticoagulant testing. Thromb Haemost 2011;105(2):385-386

74 Gosselin RC, Adcock Funk DM, Taylor JM, et al. Comparison of anti-Xa and dilute Russell viper venom time assays in quantifying drug levels in patients on therapeutic doses of rivaroxaban. Arch Pathol Lab Med 2014;138(12):1680-1684

75 Samama MM, Contant G, Spiro TE, et al; Rivaroxaban Anti-Factor Xa Chromogenic Assay Field Trial Laboratories. Evaluation of the anti-factor Xa chromogenic assay for the measurement of rivaroxaban plasma concentrations using calibrators and controls. Thromb Haemost 2012;107(2):379-387

76 Kubitza D, Becka M, Voith B, Zuehlsdorf M, Wensing G. Safety, pharmacodynamics, and pharmacokinetics of single doses of BAY 59-7939, an oral, direct factor Xa inhibitor. Clin Pharmacol Ther 2005;78(4):412-421

77 Samama MM, Amiral J, Guinet C, Perzborn E, Depasse F. An optimised, rapid chromogenic assay, specific for measuring direct factor Xa inhibitors (rivaroxaban) in plasma. Thromb Haemost 2010;104(5):1078-1079

78 Harenberg J, Krämer R, Giese C, Marx S, Weiss C, Wehling M. Determination of rivaroxaban by different factor Xa specific chromogenic substrate assays: reduction of interassay variability. J Thromb Thrombolysis 2011;32(3):267-271

79 Mani H, Rohde G, Stratmann G, et al. Accurate determination of rivaroxaban levels requires different calibrator sets but not addition of antithrombin. Thromb Haemost 2012;108(1): 191-198 
80 Douxfils J, Tamigniau A, Chatelain B, et al. Comparison of calibrated chromogenic anti-Xa assay and PT tests with LC-MS/MS for the therapeutic monitoring of patients treated with rivaroxaban. Thromb Haemost 2013;110(4):723-731

81 Adelmann D, Wiegele M, Wohlgemuth RK, et al. Measuring the activity of apixaban and rivaroxaban with rotational thromboelastometry. Thromb Res 2014;134(4):918-923

82 Levi M, Moore KT, Castillejos CF, et al. Comparison of three-factor and four-factor prothrombin complex concentrates regarding reversal of the anticoagulant effects of rivaroxaban in healthy volunteers. J Thromb Haemost 2014;12(9):1428-1436

83 Perzborn E, Heitmeier S, Laux V, Buchmüller A. Reversal of rivaroxaban-induced anticoagulation with prothrombin complex concentrate, activated prothrombin complex concentrate and recombinant activated factor VII in vitro. Thromb Res 2014; 133(4):671-681

84 Casutt M, Konrad C, Schuepfer G. Effect of rivaroxaban on blood coagulation using the viscoelastic coagulation test ROTEM ${ }^{\mathrm{TM}}$. Anaesthesist 2012;61(11):948-953

85 Bowry R, Fraser S, Archeval-Lao JM, et al. Thrombelastography detects the anticoagulant effect of rivaroxaban in patients with stroke. Stroke 2014;45(3):880-883

86 Becker RC, Alexander JH, Newby LK, et al. Effect of apixaban, an oral and direct factor Xa inhibitor, on coagulation activity biomarkers following acute coronary syndrome. Thromb Haemost 2010;104(5):976-983

87 Yamahira N, Frost C, Fukase H, et al. Safety, tolerability, pharmacokinetics, and pharmacodynamics of multiple doses of apixaban in healthy Japanese male subjects. Int J Clin Pharmacol Ther 2014; 52(7):564-573

88 Douxfils J, Chatelain C, Chatelain B, Dogné JM, Mullier F. Impact of apixaban on routine and specific coagulation assays: a practical laboratory guide. Thromb Haemost 2013;110(2):283-294

89 Gouin-Thibault I, Flaujac C, Delavenne X, et al. Assessment of apixaban plasma levels by laboratory tests: suitability of three anti-Xa assays. A multicentre French GEHT study. Thromb Haemost 2014;111(2):240-248

90 Hillarp A, Gustafsson KM, Faxälv L, et al. Effects of the oral, direct factor Xa inhibitor apixaban on routine coagulation assays and anti-FXa assays. J Thromb Haemost 2014;12(9):1545-1553

91 Harenberg J, Du S, Weiss C, Krämer R, Hoppensteadt D, Walenga $\mathrm{J}$; working party: methods to determine apixaban of the Subcommittee on Control of Anticoagulation of the International Society of Thrombosis and Haemostasis. Report of the Subcommittee on Control of Anticoagulation on the determination of the anticoagulant effects of apixaban: communication from the SSC of the ISTH. J Thromb Haemost 2014;12(5): 801-804

92 Tripodi A, Padovan L, Testa S, et al. How the direct oral anticoagulant apixaban affects hemostatic parameters. Results of a multicenter multiplatform study. Clin Chem Lab Med 2015;53(2): 265-273

93 Barrett YC, Wang Z, Knabb RM. A novel prothrombin time assay for assessing the anticoagulant activity of oral factor Xa inhibitors. Clin Appl Thromb Hemost 2013;19(5):522-528

94 Frost C, Nepal S, Wang J, et al. Safety, pharmacokinetics and pharmacodynamics of multiple oral doses of apixaban, a factor Xa inhibitor, in healthy subjects. Br J Clin Pharmacol 2013;76(5): 776-786

95 Upreti VV, Wang J, Barrett YC, et al. Effect of extremes of body weight on the pharmacokinetics, pharmacodynamics, safety and tolerability of apixaban in healthy subjects. $\mathrm{Br} \mathrm{J}$ Clin Pharmacol 2013;76(6):908-916

96 Barrett YC, Wang Z, Frost C, Shenker A. Clinical laboratory measurement of direct factor Xa inhibitors: anti-Xa assay is preferable to prothrombin time assay. Thromb Haemost 2010; 104(6):1263-1271
97 Becker RC, Yang H, Barrett Y, et al. Chromogenic laboratory assays to measure the factor Xa-inhibiting properties of apixaban-an oral, direct and selective factor Xa inhibitor. J Thromb Thrombolysis 2011;32(2):183-187

98 Frost C, Wang J, Nepal S, et al. Apixaban, an oral, direct factor Xa inhibitor: single dose safety, pharmacokinetics, pharmacodynamics and food effect in healthy subjects. Br J Clin Pharmacol 2013;75(2):476-487

99 Ogata K, Mendell-Harary J, Tachibana M, et al. Clinical safety, tolerability, pharmacokinetics, and pharmacodynamics of the novel factor Xa inhibitor edoxaban in healthy volunteers. J Clin Pharmacol 2010;50(7):743-753

100 Favaloro EJ, Plebani M, Lippi G. Regulation in hemostasis and thrombosis: part I-in vitro diagnostics. Semin Thromb Hemost 2013;39(3):235-249

101 Lippi G, Mattiuzzi C, Favaloro EJ. Thrombophilia testing in patients taking direct oral anticoagulants. Handle with care. Diagnosis 2014;1(4):311-312

102 Gómez-Outes A, Suárez-Gea ML, Lecumberri R, Terleira-Fernandez AI, Vargas-Castrillon E. Specific antidotes in development for reversal of novel anticoagulants: a review. Recent Pat Cardiovasc Drug Discov 2014;9(1):2-10

103 Zahir H, Brown KS, Vandell AG, et al. Edoxaban effects on bleeding following punch biopsy and reversal by a 4-factor prothrombin complex concentrate. Circulation 2015;131(1):82-90

104 Halim AB, Samama MM, Mendell J. Ex vivo reversal of the anticoagulant effects of edoxaban. Thromb Res 2014;134(4): 909-913

105 Fukuda T, Honda Y, Kamisato C, Morishima Y, Shibano T. Reversal of anticoagulant effects of edoxaban, an oral, direct factor Xa inhibitor, with haemostatic agents. Thromb Haemost 2012; 107(2):253-259

106 Dinkelaar J, Molenaar PJ, Ninivaggi M, de Laat B, Brinkman HJ Leyte A. In vitro assessment, using thrombin generation, of the applicability of prothrombin complex concentrate as an antidote for Rivaroxaban. J Thromb Haemost 2013;11(6): $1111-1118$

107 Sølbeck S, Nilsson CU, Engström M, Ostrowski SR, Johansson PI. Dabigatran and its reversal with recombinant factor VIIa and prothrombin complex concentrate: a Sonoclot in vitro study. Scand J Clin Lab Invest 2014;74(7):591-598

108 Körber MK, Langer E, Ziemer S, Perzborn E, Gericke C, Heymann $\mathrm{Cv}$. Measurement and reversal of prophylactic and therapeutic peak levels of rivaroxaban: an in vitro study. Clin Appl Thromb Hemost 2014;20(7):735-740

109 Eerenberg ES, Kamphuisen PW, Sijpkens MK, Meijers JC, Buller HR, Levi M. Reversal of rivaroxaban and dabigatran by prothrombin complex concentrate: a randomized, placebo-controlled, crossover study in healthy subjects. Circulation 2011;124(14): 1573-1579

110 Dinkelaar J, Patiwael S, Harenberg J, Leyte A, Brinkman HJ. Global coagulation tests: their applicability for measuring direct factor $\mathrm{Xa}-$ and thrombin inhibition and reversal of anticoagulation by prothrombin complex concentrate. Clin Chem Lab Med 2014; 52(11):1615-1623

111 Davis PK, Musunuru H, Walsh M, Mitra R, Ploplis V, Castellino FJ The ex vivo reversibility of dabigatran-induced whole-blood coagulopathy as monitored by thromboelastography: mechanistic implications for clinical medicine. Thromb Haemost 2012; 108(3):586-588

112 Marlu R, Hodaj E, Paris A, Albaladejo P, Cracowski JL, Pernod G. Effect of non-specific reversal agents on anticoagulant activity of dabigatran and rivaroxaban: a randomised crossover ex vivo study in healthy volunteers. Thromb Haemost 2012;108(2): 217-224

113 Di Minno A, Spadarella G, Prisco D, Franchini M, Lupoli R, Di Minno MN. Clinical judgment when using coagulation tests 
during direct oral anticoagulant treatment: a concise review. Semin Thromb Hemost 2013;39(7):840-846

114 Favaloro EJ, Bonar R, Butler J, Marsden K. Laboratory testing for the new oral anticoagulants: a review of current practice. Pathology 2013;45(4):435-437

115 Harenberg J, Krämer S, Du S, Weiss C, Krämer R. Concept of a point of care test to detect new oral anticoagulants in urine samples. Thromb J 2013;11(1):15

116 Harenberg J, Du S, Krämer S, et al. Novel methods for assessing oral direct factor Xa and thrombin inhibitors: use of point-of-care testing and urine samples. Semin Thromb Hemost 2013;39(1): 66-71

117 Harenberg J, Kraemer R. Measurement of the new anticoagulants. Thromb Res 2012;129(Suppl 1):S106-S113

118 Harenberg J, Krämer S, Du S, et al. Measurement of rivaroxaban and apixaban in serum samples of patients. Eur J Clin Invest 2014; 44(8):743-752

119 Harenberg J, Kraemer S, Du S, et al. Determination of direct oral anticoagulants from human serum samples. Semin Thromb Hemost 2014;40(1):129-134 


\section{Appendix A}

\begin{tabular}{|c|c|}
\hline $\begin{array}{l}\text { Appendix } \\
\text { reference } \\
\text { number }\end{array}$ & Reference citation \\
\hline 1 & $\begin{array}{l}\text { Kubitza D, Becka M, Voith B, Zuehlsdorf M, Wensing G. Safety, pharmacodynamics, and pharmacokinetics of } \\
\text { single doses of BAY 59-7939, an oral, direct factor Xa inhibitor. Clin Pharmacol Ther 2005;78(4):412-421 }\end{array}$ \\
\hline 2 & $\begin{array}{l}\text { Stangier J, Rathgen K, Stähle H, Gansser D, Roth W. The pharmacokinetics, pharmacodynamics and tolerability of } \\
\text { dabigatran etexilate, a new oral direct thrombin inhibitor, in healthy male subjects. Br J Clin Pharmacol 2007;64 } \\
\text { (3):292-303 }\end{array}$ \\
\hline 3 & $\begin{array}{l}\text { Stangier J, Stähle H, Rathgen K, Fuhr R. Pharmacokinetics and pharmacodynamics of the direct oral thrombin } \\
\text { inhibitor dabigatran in healthy elderly subjects. Clin Pharmacokinet } 2008 ; 47(1): 47-59\end{array}$ \\
\hline 4 & $\begin{array}{l}\text { Harder S, Parisius J, Picard-Willems B. Monitoring direct FXa-inhibitors and fondaparinux by Prothrombinase- } \\
\text { induced Clotting Time (PiCT): relation to FXa-activity and influence of assay modifications. Thromb Res 2008;123 } \\
\text { (2):396-403 }\end{array}$ \\
\hline 5 & $\begin{array}{l}\text { Borris LC, Breindahl M, Lassen MR, Pap AF, Misselwitz F. Differences in urinary prothrombin fragment } 1+2 \text { levels } \\
\text { after total hip replacement in relation to venous thromboembolism and bleeding events. J Thromb Haemost } \\
\text { 2008;6(10):1671-1679 }\end{array}$ \\
\hline 6 & $\begin{array}{l}\text { Samama MM, Martinoli JL, LeFlem L, et al. Assessment of laboratory assays to measure rivaroxaban-an oral, direct } \\
\text { factor Xa inhibitor. Thromb Haemost 2010;103(4):815-825 }\end{array}$ \\
\hline 7 & $\begin{array}{l}\text { van Ryn J, Stangier J, Haertter S, et al. Dabigatran etexilate-a novel, reversible, oral direct thrombin inhibitor: } \\
\text { interpretation of coagulation assays and reversal of anticoagulant activity. Thromb Haemost 2010;103(6): } \\
1116-1127\end{array}$ \\
\hline 8 & $\begin{array}{l}\text { Samama MM, Amiral J, Guinet C, Perzborn E, Depasse F. An optimised, rapid chromogenic assay, specific for } \\
\text { measuring direct factor Xa inhibitors (rivaroxaban) in plasma. Thromb Haemost 2010;104(5):10781079 }\end{array}$ \\
\hline 9 & $\begin{array}{l}\text { Becker RC, Alexander JH, Newby LK, et al. Effect of apixaban, an oral and direct factor Xa inhibitor, on coagulation } \\
\text { activity biomarkers following acute coronary syndrome. Thromb Haemost 2010;104(5):976-983 }\end{array}$ \\
\hline 10 & $\begin{array}{l}\text { Tripodi A, Chantarangkul V, Guinet C, Samama MM. The International Normalized Ratio calibrated for rivaroxaban } \\
\text { has the potential to normalize prothrombin time results for rivaroxaban-treated patients: results of an in vitro } \\
\text { study. J Thromb Haemost } 2011 ; 9(1): 226-228\end{array}$ \\
\hline 11 & $\begin{array}{l}\text { Hillarp A, Baghaei F, Fagerberg Blixter I, et al. Effects of the oral, direct factor Xa inhibitor rivaroxaban on } \\
\text { commonly used coagulation assays. J Thromb Haemost } 2011 ; 9(1): 133-139\end{array}$ \\
\hline 12 & $\begin{array}{l}\text { Barrett YC, Wang Z, Frost C, Shenker A. Clinical laboratory measurement of direct factor Xa inhibitors: anti-Xa } \\
\text { assay is preferable to prothrombin time assay. Thromb Haemost 2010;104(6):1263-1271 }\end{array}$ \\
\hline 13 & $\begin{array}{l}\text { Lindahl TL, Baghaei F, Blixter IF, et al; Expert Group on Coagulation of the External Quality Assurance in Laboratory } \\
\text { Medicine in Sweden. Effects of the oral, direct thrombin inhibitor dabigatran on five common coagulation assays. } \\
\text { Thromb Haemost } 2011 ; 105(2): 371-378\end{array}$ \\
\hline 14 & $\begin{array}{l}\text { Becker RC, Yang H, Barrett Y, et al. Chromogenic laboratory assays to measure the factor Xa-inhibiting properties } \\
\text { of apixaban-an oral, direct and selective factor Xa inhibitor. J Thromb Thrombolysis } 2011 ; 32(2): 183-187\end{array}$ \\
\hline 15 & $\begin{array}{l}\text { Wolzt M, Samama MM, Kapiotis S, Ogata K, Mendell J, Kunitada S. Effect of edoxaban on markers of coagulation in } \\
\text { venous and shed blood compared with fondaparinux. Thromb Haemost 2011;105(6):1080-1090 }\end{array}$ \\
\hline 16 & $\begin{array}{l}\text { Baruch L, Sherman O. Potential inaccuracy of point-of-care INR in dabigatran-treated patients. Ann Pharmacother } \\
2011 ; 45(7-8): \mathrm{e} 40\end{array}$ \\
\hline 17 & $\begin{array}{l}\text { Harenberg J, Krämer R, Giese C, Marx S, Weiss C, Wehling M. Determination of rivaroxaban by different factor Xa } \\
\text { specific chromogenic substrate assays: reduction of interassay variability. J Thromb Thrombolysis 2011;32 } \\
\text { (3):267-271 }\end{array}$ \\
\hline 18 & $\begin{array}{l}\text { Merriman E, Kaplan Z, Butler J, Malan E, Gan E, Tran H. Rivaroxaban and false positive lupusanticoagulant testing. } \\
\text { Thromb Haemost 2011;105:385-386 }\end{array}$ \\
\hline 19 & $\begin{array}{l}\text { Freyburger G, Macouillard G, Labrouche S, Sztark F. Coagulation parameters in patients receiving dabigatran } \\
\text { etexilate or rivaroxaban: Two observational studies in patients undergoing total hip or total knee replacement. } \\
\text { Thromb Res 2011;127:457-465 }\end{array}$ \\
\hline 20 & $\begin{array}{l}\text { Asmis LM, Alberio L, Angelillo-Scherrer A, et al. Rivaroxaban: quantification by anti-FXa assay and influence on } \\
\text { coagulation tests: a study in } 9 \text { Swiss laboratories. Thromb Res } 2012 ; 129(4): 492-498\end{array}$ \\
\hline 21 & $\begin{array}{l}\text { Eerenberg ES, Kamphuisen PW, Sijpkens MK, Meijers JC, Buller HR, Levi M. Reversal of rivaroxaban and dabigatran } \\
\text { by prothrombin complex concentrate: a randomized, placebo-controlled, crossover study in healthy subjects. } \\
\text { Circulation 2011;124(14):1573-1579 }\end{array}$ \\
\hline
\end{tabular}


Appendix A (Continued)

\begin{tabular}{|c|c|}
\hline $\begin{array}{l}\text { Appendix } \\
\text { reference } \\
\text { number }\end{array}$ & Reference citation \\
\hline 22 & $\begin{array}{l}\text { Harenberg J, Marx S, Krämer R, Giese C, Weiss C. Determination of an international sensitivity index of } \\
\text { thromboplastin reagents using a WHO thromboplastin as calibrator for plasma spiked with rivaroxaban. Blood } \\
\text { Coagul Fibrinolysis } 2011 ; 22(8): 637-641\end{array}$ \\
\hline 23 & $\begin{array}{l}\text { Gerotziafas GT, Baccouche H, Sassi M, et al. Optimisation of the assays for the measurement of clotting factor } \\
\text { activity in the presence of rivaroxaban. Thromb Res 2012;129(1):101-103 }\end{array}$ \\
\hline 24 & $\begin{array}{l}\text { Fukuda T, Honda Y, Kamisato C, Morishima Y, Shibano T. Reversal of anticoagulant effects of edoxaban, an oral, } \\
\text { direct factor Xa inhibitor, with haemostatic agents. Thromb Haemost 2012;107(2):253-259 }\end{array}$ \\
\hline 25 & $\begin{array}{l}\text { Samama MM, Contant G, Spiro TE, et al; Rivaroxaban Anti-Factor Xa Chromogenic Assay Field Trial Laboratories. } \\
\text { Evaluation of the anti-factor Xa chromogenic assay for the measurement of rivaroxaban plasma concentrations } \\
\text { using calibrators and controls. Thromb Haemost 2012;107(2):379-387 }\end{array}$ \\
\hline 26 & $\begin{array}{l}\text { Kubitza D, Becka M, Mück W, Schwers S. Effect of co-administration of rivaroxaban and clopidogrel on bleeding } \\
\text { time, pharmacodynamics and pharmacokinetics: a phase I study. Pharmaceuticals (Basel) 2012;5(3):279-296 }\end{array}$ \\
\hline 27 & $\begin{array}{l}\text { Stangier J, Feuring M. Using the HEMOCLOT direct thrombin inhibitor assay to determine plasma concentrations } \\
\text { of dabigatran. Blood Coagul Fibrinolysis 2012;23(2):138-143 }\end{array}$ \\
\hline 28 & $\begin{array}{l}\text { van Ryn J, Baruch L, Clemens A. Interpretation of point-of-care INR results in patients treated with dabigatran. Am } \\
\text { J Med 2012;125(4):417-420 }\end{array}$ \\
\hline 29 & $\begin{array}{l}\text { Harenberg J, Giese C, Marx S, Krämer R. Determination of dabigatran in human plasma samples. Semin Thromb } \\
\text { Hemost 2012;38(1):16-22 }\end{array}$ \\
\hline 30 & $\begin{array}{l}\text { Funatsu T, Iwatsuki Y, Kaku S. Darexaban has high sensitivity in the prothrombin time clotting test. J Thromb } \\
\text { Haemost 2012;10(4):703-705 }\end{array}$ \\
\hline 31 & $\begin{array}{l}\text { Samama MM, Contant G, Spiro TE, et al; Rivaroxaban Prothrombin Time Field Trial Laboratories. Evaluation of the } \\
\text { prothrombin time for measuring rivaroxaban plasma concentrations using calibrators and controls: results of a } \\
\text { multicenter field trial. Clin Appl Thromb Hemost 2012;18(2):150-158 }\end{array}$ \\
\hline 32 & $\begin{array}{l}\text { Barrett YC, Wang J, Song Y, et al. A randomised assessment of the pharmacokinetic, pharmacodynamic and safety } \\
\text { interaction between apixaban and enoxaparin in healthy subjects. Thromb Haemost 2012;107(5):916-924 }\end{array}$ \\
\hline 33 & $\begin{array}{l}\text { Harenberg J, Erdle S, Marx S, Krämer R. Determination of rivaroxaban in human plasma samples. Semin Thromb } \\
\text { Hemost 2012;38(2):178-184 }\end{array}$ \\
\hline 34 & $\begin{array}{l}\text { Avecilla ST, Ferrell C, Chandler WL, Reyes M. Plasma-diluted thrombin time to measure dabigatran concentrations } \\
\text { during dabigatran etexilate therapy. Am J Clin Pathol 2012;137(4):572-574 }\end{array}$ \\
\hline 35 & $\begin{array}{l}\text { Douxfils J, Mullier F, Robert S, Chatelain C, Chatelain B, Dogné JM. Impact of dabigatran on a large panel of routine } \\
\text { or specific coagulation assays. Laboratory recommendations for monitoring of dabigatran etexilate. Thromb } \\
\text { Haemost 2012;107(5):985-997 }\end{array}$ \\
\hline 36 & Harenberg J, Kraemer R. Measurement of the new anticoagulants. Thromb Res 2012;129 (Suppl 1):S106-S113 \\
\hline 37 & $\begin{array}{l}\text { Barrett YC, Wang Z, Knabb RM. A novel prothrombin time assay for assessing the anticoagulant activity of oral } \\
\text { factor Xa inhibitors. Clin Appl Thromb Hemost 2013;19(5):522-528 }\end{array}$ \\
\hline 38 & $\begin{array}{l}\text { Barton CA, McMillian WD, Raza SS, Keller RE. Hemopericardium in a patient treated with dabigatran etexilate. } \\
\text { Pharmacotherapy 2012;32(5):e103-e107 }\end{array}$ \\
\hline 39 & $\begin{array}{l}\text { Mani H, Rohde G, Stratmann G, et al. Accurate determination of rivaroxaban levels requires different calibrator } \\
\text { sets but not addition of antithrombin. Thromb Haemost 2012;108(1):191-198 }\end{array}$ \\
\hline 40 & $\begin{array}{l}\text { Marlu R, Hodaj E, Paris A, Albaladejo P, Cracowski JL, Pernod G. Effect of non-specific reversal agents on } \\
\text { anticoagulant activity of dabigatran and rivaroxaban: a randomised crossover ex vivo study in healthy volunteers. } \\
\text { Thromb Haemost } 2012 ; 108(2): 217-224\end{array}$ \\
\hline 41 & $\begin{array}{l}\text { Béné J, Saïd W, Rannou M, Deheul S, Coupe P, Gautier S. Rectal bleeding and hemostatic disorders induced by } \\
\text { dabigatran etexilate in } 2 \text { elderly patients. Ann Pharmacother 2012;46(6):e14 }\end{array}$ \\
\hline 42 & $\begin{array}{l}\text { Frost C, Wang J, Nepal S, et al. Apixaban, an oral, direct factor Xa inhibitor: single dose safety, pharmacokinetics, } \\
\text { pharmacodynamics and food effect in healthy subjects. Br J Clin Pharmacol 2013;75(2):476-487 }\end{array}$ \\
\hline 43 & $\begin{array}{l}\text { Davis PK, Musunuru H, Walsh M, Mitra R, Ploplis V, Castellino FJ. The ex vivo reversibility of dabigatran-induced } \\
\text { whole-blood coagulopathy as monitored by thromboelastography: mechanistic implications for clinical medi- } \\
\text { cine. Thromb Haemost 2012;108(3):586-588 }\end{array}$ \\
\hline 44 & $\begin{array}{l}\text { Stief TW. Determination of the anti-F10a or anti-F2a generation action of rivaroxaban or dabigatran. Blood Coagul } \\
\text { Fibrinolysis 2012;23(7):619-621 }\end{array}$ \\
\hline
\end{tabular}


Appendix A (Continued)

\begin{tabular}{|c|c|}
\hline $\begin{array}{l}\text { Appendix } \\
\text { reference } \\
\text { number }\end{array}$ & Reference citation \\
\hline 45 & $\begin{array}{l}\text { He S, Wallèn H, Bark N, Blombäck M. In vitro studies using a global hemostasis assay to examine the } \\
\text { anticoagulation effects in plasma by the direct thrombin inhibitors: dabigatran and argatroban. J Thromb } \\
\text { Thrombolysis } 2013 ; 35(2): 131-139\end{array}$ \\
\hline 46 & $\begin{array}{l}\text { Attard C, Monagle P, Kubitza D, Ignjatovic V. The in vitro anticoagulant effect of rivaroxaban in children. Thromb } \\
\text { Res 2012;130(5):804-807 }\end{array}$ \\
\hline 47 & Jones SD, Eaddy NS, Chan GT. Dabigatran: laboratory monitoring. Pathology 2012;44(6):578-580 \\
\hline 48 & $\begin{array}{l}\text { Douxfils J, Mullier F, Loosen C, Chatelain C, Chatelain B, Dogné JM. Assessment of the impact of rivaroxaban on } \\
\text { coagulation assays: laboratory recommendations for the monitoring of rivaroxaban and review of the literature. } \\
\text { Thromb Res 2012;130(6):956-966 }\end{array}$ \\
\hline 49 & $\begin{array}{l}\text { Khoo TL, Weatherburn C, Kershaw G, Reddel CJ, Curnow J, Dunkley S. The use of FEIBA® in the correction of } \\
\text { coagulation abnormalities induced by dabigatran. Int J Lab Hematol 2013;35(2):222-224 }\end{array}$ \\
\hline 50 & $\begin{array}{l}\text { Casutt M, Konrad C, Schuepfer G. Effect of rivaroxaban on blood coagulation using the viscoelastic coagulation } \\
\text { test ROTEM }{ }^{\text {TM }} \text {. Anaesthesist 2012;61(11):948-953 }\end{array}$ \\
\hline 51 & $\begin{array}{l}\text { Molenaar PJ, Dinkelaar J, Leyte A. Measuring rivaroxaban in a clinical laboratory setting, using common } \\
\text { coagulation assays, Xa inhibition and thrombin generation. Clin Chem Lab Med 2012;50(10):1799-1807 }\end{array}$ \\
\hline 52 & $\begin{array}{l}\text { Halbmayer WM, Weigel G, Quehenberger P, et al. Interference of the new oral anticoagulant dabigatran with } \\
\text { frequently used coagulation tests. Clin Chem Lab Med 2012;50(9):1601-1605 }\end{array}$ \\
\hline 53 & $\begin{array}{l}\text { Kluft C, Meijer P, Kret R, Burggraaf J. Preincubation in the Prothrombinase-induced Clotting Time test (PiCT) is } \\
\text { necessary for in vitro evaluation of fondaparinux and to be avoided for the reversible, direct factor Xa inhibitor, } \\
\text { rivaroxaban. Int J Lab Hematol 2013;35(4):379-384 }\end{array}$ \\
\hline 54 & $\begin{array}{l}\text { Dager WE, Gosselin RC, Kitchen S, Dwyre D. Dabigatran effects on the international normalized ratio, activated } \\
\text { partial thromboplastin time, thrombin time, and fibrinogen: a multicenter, in vitro study. Ann Pharmacother } \\
2012 ; 46(12): 1627-1636\end{array}$ \\
\hline 55 & $\begin{array}{l}\text { Harenberg J, Du S, Krämer S, et al. Novel methods for assessing oral direct factor Xa and thrombin inhibitors: use } \\
\text { of point-of-care testing and urine samples. Semin Thromb Hemost 2013;39(1):66-71 }\end{array}$ \\
\hline 56 & $\begin{array}{l}\text { Varin R, Mirshahi S, Mirshahi P, et al. Whole blood clots are more resistant to lysis than plasma clots-greater } \\
\text { efficacy of rivaroxaban. Thromb Res 2013;131(3):e100-e109 }\end{array}$ \\
\hline 57 & $\begin{array}{l}\text { Samama MM, Guinet C, Le Flem L, Ninin E, Debue JM. Measurement of dabigatran and rivaroxaban in primary } \\
\text { prevention of venous thromboembolism in } 106 \text { patients, who have undergone major orthopedic surgery: an } \\
\text { observational study. J Thromb Thrombolysis 2013;35(2):140-146 }\end{array}$ \\
\hline 58 & $\begin{array}{l}\text { Xu Y, Wu W, Wang L, et al. Differential profiles of thrombin inhibitors (heparin, hirudin, bivalirudin, and } \\
\text { dabigatran) in the thrombin generation assay and thromboelastography in vitro. Blood Coagul Fibrinolysis } \\
2013 ; 24(3): 332-338\end{array}$ \\
\hline 59 & $\begin{array}{l}\text { Helin TA, Pakkanen A, Lassila R, Joutsi-Korhonen L. Laboratory assessment of novel oral anticoagulants: method } \\
\text { suitability and variability between coagulation laboratories. Clin Chem 2013;59(5):807-814 }\end{array}$ \\
\hline 60 & $\begin{array}{l}\text { Frost C, Nepal S, Wang J, et al. Safety, pharmacokinetics and pharmacodynamics of multiple oral doses of } \\
\text { apixaban, a factor Xa inhibitor, in healthy subjects. } \mathrm{Br} \text { J Clin Pharmacol 2013;76(5):776-786 }\end{array}$ \\
\hline 61 & $\begin{array}{l}\text { Upreti VV, Wang J, Barrett YC, et al. Effect of extremes of body weight on the pharmacokinetics, } \\
\text { pharmacodynamics, safety and tolerability of apixaban in healthy subjects. Br J Clin Pharmacol } \\
\text { 2013;76(6):908-916 }\end{array}$ \\
\hline 62 & $\begin{array}{l}\text { Dinkelaar J, Molenaar PJ, Ninivaggi M, de Laat B, Brinkman HJ, Leyte A. In vitro assessment, using thrombin } \\
\text { generation, of the applicability of prothrombin complex concentrate as an antidote for Rivaroxaban. J Thromb } \\
\text { Haemost } 2013 ; 11(6): 1111-1118\end{array}$ \\
\hline 63 & $\begin{array}{l}\text { Hawes EM, Deal AM, Funk-Adcock D, et al. Performance of coagulation tests in patients on therapeutic doses of } \\
\text { dabigatran: a cross-sectional pharmacodynamic study based on peak and trough plasma levels. J Thromb } \\
\text { Haemost } 2013 ; 11(8): 1493-1502\end{array}$ \\
\hline 64 & $\begin{array}{l}\text { Douxfils J, Chatelain C, Chatelain B, Dogné JM, Mullier F. Impact of apixaban on routine and specific coagulation } \\
\text { assays: a practical laboratory guide. Thromb Haemost 2013;110(2):283-294 }\end{array}$ \\
\hline 65 & $\begin{array}{l}\text { Douxfils J, Dogné JM, Mullier F, et al. Comparison of calibrated dilute thrombin time and aPTT tests with LC-MS/MS } \\
\text { for the therapeutic monitoring of patients treated with dabigatran etexilate. Thromb Haemost 2013;110(3): } \\
543-549\end{array}$ \\
\hline
\end{tabular}




\begin{tabular}{|c|c|}
\hline $\begin{array}{l}\text { Appendix } \\
\text { reference } \\
\text { number }\end{array}$ & Reference citation \\
\hline 66 & $\begin{array}{l}\text { Hapgood G, Butler J, Malan E, Chunilal S, Tran H. The effect of dabigatran on the activated partial thromboplastin } \\
\text { time and thrombin time as determined by the Hemoclot thrombin inhibitor assay in patient plasma samples. } \\
\text { Thromb Haemost } 2013 ; 110(2): 308-315\end{array}$ \\
\hline 67 & $\begin{array}{l}\text { Antovic JP, Skeppholm M, Eintrei J, et al. Evaluation of coagulation assays versus LC-MS/MS for determinations of } \\
\text { dabigatran concentrations in plasma. Eur J Clin Pharmacol 2013;69(11):1875-1881 }\end{array}$ \\
\hline 68 & $\begin{array}{l}\text { Körber MK, Langer E, Ziemer S, Perzborn E, Gericke C, Heymann Cv. Measurement and reversal of prophylactic } \\
\text { and therapeutic peak levels of rivaroxaban: an in vitro study. Clin Appl Thromb Hemost 2014;20(7):735-740 }\end{array}$ \\
\hline 69 & $\begin{array}{l}\text { Douxfils J, Tamigniau A, Chatelain B, et al. Comparison of calibrated chromogenic anti-Xa assay and PT tests with } \\
\text { LC-MS/MS for the therapeutic monitoring of patients treated with rivaroxaban. Thromb Haemost 2013;110 } \\
\text { (4):723-731 }\end{array}$ \\
\hline 70 & $\begin{array}{l}\text { Harenberg J, Krämer S, Du S, Weiss C, Krämer R. Concept of a point of care test to detect new oral anticoagulants } \\
\text { in urine samples. Thromb J 2013;11(1):15 }\end{array}$ \\
\hline 71 & $\begin{array}{l}\text { Sairaku A, Yoshida Y, Ando M, Hirayama H, Nakano Y, Kihara Y. A head-to-head comparison of periprocedural } \\
\text { coagulability under anticoagulation with rivaroxaban versus dabigatran in patients undergoing ablation of atrial } \\
\text { fibrillation. Clin Drug Investig 2013;33(11):847-853 }\end{array}$ \\
\hline 72 & $\begin{array}{l}\text { Kim J, Yadava M, An IC, et al. Coagulopathy and extremely elevated PT/INR after dabigatran etexilate use in a } \\
\text { patient with end-stage renal disease. Case Rep Med 2013;2013:131395 }\end{array}$ \\
\hline 73 & $\begin{array}{l}\text { Gouin-Thibault I, Flaujac C, Delavenne X, et al. Assessment of apixaban plasma levels by laboratory tests: } \\
\text { suitability of three anti-Xa assays. A multicentre French GEHT study. Thromb Haemost 2014;111(2):240-248 }\end{array}$ \\
\hline 74 & $\begin{array}{l}\text { Potze W, Arshad F, Adelmeijer J, et al. Routine coagulation assays underestimate levels of antithrombin- } \\
\text { dependent drugs but not of direct anticoagulant drugs in plasma from patients with cirrhosis. Br J Haematol } \\
2013 ; 163(5): 666-673\end{array}$ \\
\hline 75 & $\begin{array}{l}\text { Gosselin RC, Dwyre DM, Dager WE. Measuring dabigatran concentrations using a chromogenic ecarin clotting } \\
\text { time assay. Ann Pharmacother 2013;47(12):1635-1640 }\end{array}$ \\
\hline 76 & $\begin{array}{l}\text { Baruch L, Sherman O. Inaccuracy of point-of-care international normalized ratio in rivaroxaban-treated patients. } \\
\text { Ann Pharmacother 2013;47(9):1210-1212 }\end{array}$ \\
\hline 77 & $\begin{array}{l}\text { Herrmann R, Thom J, Wood A, Phillips M, Muhammad S, Baker R. Thrombin generation using the calibrated } \\
\text { automated thrombinoscope to assess reversibility of dabigatran and rivaroxaban. Thromb Haemost 2014;111 } \\
\text { (5):989-995 }\end{array}$ \\
\hline 78 & $\begin{array}{l}\text { Harenberg J, Kraemer S, Du S, et al. Determination of direct oral anticoagulants from human serum samples. } \\
\text { Semin Thromb Hemost 2014;40(1):129-134 }\end{array}$ \\
\hline 79 & $\begin{array}{l}\text { Meyer Dos Santos S, Zorn A, Guttenberg Z, et al. A novel } \mu \text {-fluidic whole blood coagulation assay based on } \\
\text { Rayleigh surface-acoustic waves as a point-of-care method to detect anticoagulants. Biomicrofluidics } 2013 ; 7 \\
\text { (5):56502 }\end{array}$ \\
\hline 80 & $\begin{array}{l}\text { Exner T, Ellwood L, Rubie J, Barancewicz A. Testing for new oral anticoagulants with LA-resistant Russells viper } \\
\text { venom reagents. An in vitro study. Thromb Haemost 2013;109(4):762-765 }\end{array}$ \\
\hline 81 & $\begin{array}{l}\text { Eller T, Busse J, Dittrich M, et al. Dabigatran, rivaroxaban, apixaban, argatroban and fondaparinux and their effects } \\
\text { on coagulation POC and platelet function tests. Clin Chem Lab Med 2014;52(6):835-844 }\end{array}$ \\
\hline 82 & $\begin{array}{l}\text { Bowry R, Fraser S, Archeval-Lao JM, et al. Thrombelastography detects the anticoagulant effect of rivaroxaban in } \\
\text { patients with stroke. Stroke } 2014 ; 45(3): 880-883\end{array}$ \\
\hline 83 & $\begin{array}{l}\text { Gosselin R, Hawes E, Moll S, Adcock D. Performance of various laboratory assays in the measurement of } \\
\text { dabigatran in patients receiving therapeutic doses: a prospective study based on peak and trough plasma levels. } \\
\text { Am J Clin Pathol } 2014 ; 141(2): 262-267\end{array}$ \\
\hline 84 & $\begin{array}{l}\text { Hosokawa K, Ohnishi T, Sameshima H, et al. Comparative evaluation of direct thrombin and factor Xa inhibitors } \\
\text { with antiplatelet agents under flow and static conditions: an in vitro flow chamber model. PLoS One 2014;9(1): } \\
\text { e86491 }\end{array}$ \\
\hline 85 & $\begin{array}{l}\text { Potze W, Arshad F, Adelmeijer J, et al. Differential in vitro inhibition of thrombin generation by anticoagulant } \\
\text { drugs in plasma from patients with cirrhosis. PLoS One } 2014 ; 9(2) \text { :e } 88390\end{array}$ \\
\hline 86 & $\begin{array}{l}\text { Kubitza D, Becka M, Mück W, Krätzschmar J. Pharmacodynamics and pharmacokinetics during the transition from } \\
\text { warfarin to rivaroxaban: a randomized study in healthy subjects. Br J Clin Pharmacol 2014;78(2):353-363 }\end{array}$ \\
\hline 87 & $\begin{array}{l}\text { Mani H, Herth N, Kasper A, et al. Point-of-care coagulation testing for assessment of the pharmacodynamic } \\
\text { anticoagulant effect of direct oral anticoagulant. Ther Drug Monit 2014;36(5):624-631 }\end{array}$ \\
\hline
\end{tabular}


Appendix A (Continued)

\begin{tabular}{|c|c|}
\hline $\begin{array}{l}\text { Appendix } \\
\text { reference } \\
\text { number }\end{array}$ & Reference citation \\
\hline 88 & $\begin{array}{l}\text { Chin PK, Wright DF, Patterson DM, Doogue MP, Begg EJ. A proposal for dose-adjustment of dabigatran etexilate in } \\
\text { atrial fibrillation guided by thrombin time. Br J Clin Pharmacol 2014;78(3):599-609 }\end{array}$ \\
\hline 89 & $\begin{array}{l}\text { Yamamoto J, Inoue N, Otsui K, Ishii H, Gorog DA. Global Thrombosis Test (GTT) can detect major determinants of } \\
\text { haemostasis including platelet reactivity, endogenous fibrinolytic and thrombin generating potential. Thromb } \\
\text { Res 2014;133(5):919-926 }\end{array}$ \\
\hline 90 & $\begin{array}{l}\text { Stang L, Nahirniak S, Butcher K, Szkotak AJ. Dabigatran assessment in patients with acute complications using } \\
\text { routine coagulation assays. Blood Coagul Fibrinolysis 2014;25(5):426-434 }\end{array}$ \\
\hline 91 & $\begin{array}{l}\text { Lind SE, Boyle ME, Fisher S, Ishimoto J, Trujillo TC, Kiser TH. Comparison of the aPTT with alternative tests for } \\
\text { monitoring direct thrombin inhibitors in patient samples. Am J Clin Pathol 2014;141(5):665-674 }\end{array}$ \\
\hline 92 & $\begin{array}{l}\text { Yamahira N, Frost C, Fukase H, et al. Safety, tolerability, pharmacokinetics, and pharmacodynamics of multiple } \\
\text { doses of apixaban in healthy Japanese male subjects. Int J Clin Pharmacol Ther 2014;52(7):564-573 }\end{array}$ \\
\hline 93 & $\begin{array}{l}\text { Sümnig A, Grotevendt A, Westphal A, Fiene M, Greinacher A, Thiele T. Acquired hemophilia with inhibitors } \\
\text { presenting as an emergency: misinterpretation of clotting results during direct oral anticoagulation. Dtsch } \\
\text { Arztebl Int 2014;111(19):345-348 }\end{array}$ \\
\hline 94 & $\begin{array}{l}\text { Stevenson JW, Minns AB, Smollin C, et al. An observational case series of dabigatran and rivaroxaban exposures } \\
\text { reported to a poison control system. Am J Emerg Med 2014;32(9):1077-1084 }\end{array}$ \\
\hline 95 & $\begin{array}{l}\text { Sølbeck S, Nilsson CU, Engström M, Ostrowski SR, Johansson PI. Dabigatran and its reversal with recombinant } \\
\text { factor VIla and prothrombin complex concentrate: A Sonoclot in vitro study. Scand J Clin Lab Invest 2014;74: } \\
591-598\end{array}$ \\
\hline 96 & $\begin{array}{l}\text { Harenberg J, Krämer S, Du S, et al. Measurement of rivaroxaban and apixaban in serum samples of patients. Eur J } \\
\text { Clin Invest 2014;44(8):743-752 }\end{array}$ \\
\hline 97 & $\begin{array}{l}\text { Tsutsumi Y, Shimono J, Ohhigashi H, Ito S, Shiratori S, Teshima T. Analysis of the influence of dabigatran on } \\
\text { coagulation factors and inhibitors. Int J Lab Hematol } 2014 \text { Jun } 25 \text {. doi: } 10.1111 / \text { ijlh. } 12270 \text {. }\end{array}$ \\
\hline 98 & $\begin{array}{l}\text { Hillarp A, Gustafsson KM, Faxälv L, et al. Effects of the oral, direct factor Xa inhibitor apixaban on routine } \\
\text { coagulation assays and anti-FXa assays. J Thromb Haemost } 2014 ; 12(9): 1545-1553\end{array}$ \\
\hline 99 & $\begin{array}{l}\text { Linkins LA, Moffat K. Monitoring the anticoagulant effect after a massive rivaroxaban overdose. J Thromb } \\
\text { Haemost 2014;12(9):1570-1571 }\end{array}$ \\
\hline 100 & $\begin{array}{l}\text { Samoš M, Stančiaková L, Ivanková J, et al. Monitoring of dabigatran therapy using Hemoclot(®) Thrombin } \\
\text { Inhibitor assay in patients with atrial fibrillation. J Thromb Thrombolysis 2015;39(1):95-100 }\end{array}$ \\
\hline 101 & $\begin{array}{l}\text { Schmitz EM, Boonen K, van den Heuvel DJ, et al. Determination of dabigatran, rivaroxaban and apixaban by ultra- } \\
\text { performance liquid chromatography - tandem mass spectrometry (UPLC-MS/MS) and coagulation assays for } \\
\text { therapy monitoring of novel direct oral anticoagulants. J Thromb Haemost 2014;12(10):1636-1646 }\end{array}$ \\
\hline 102 & $\begin{array}{l}\text { Tripodi A, Padovan L, Testa S, et al. How the direct oral anticoagulant apixaban affects hemostatic parameters. } \\
\text { Results of a multicenter multiplatform study. Clin Chem Lab Med 2015;53(2):265-273 }\end{array}$ \\
\hline 103 & $\begin{array}{l}\text { Solbeck S, Meyer MA, Johansson PI, et al. Monitoring of dabigatran anticoagulation and its reversal in vitro by } \\
\text { thrombelastography. Int J Cardiol 2014;176(3):794-799 }\end{array}$ \\
\hline 104 & $\begin{array}{l}\text { van Ryn J, Grottke O, Spronk H. Measurement of dabigatran in standardly used clinical assays, whole blood } \\
\text { viscoelastic coagulation, and thrombin generation assays. Clin Lab Med 2014;34(3):479-501 }\end{array}$ \\
\hline 105 & $\begin{array}{l}\text { Skeppholm M, HjemdahI P, Antovic JP, et al. On the monitoring of dabigatran treatment in "real life" patients with } \\
\text { atrial fibrillation. Thromb Res } 2014 ; 134(4): 783-789\end{array}$ \\
\hline 106 & $\begin{array}{l}\text { Adelmann D, Wiegele M, Wohlgemuth RK, et al. Measuring the activity of apixaban and rivaroxaban with } \\
\text { rotational thromboelastometry. Thromb Res 2014;134(4):918-923 }\end{array}$ \\
\hline 107 & $\begin{array}{l}\text { Halim AB, Samama MM, Mendell J. Ex vivo reversal of the anticoagulant effects of edoxaban. Thromb Res } \\
\text { 2014;134(4):909-913 }\end{array}$ \\
\hline 108 & $\begin{array}{l}\text { Tajiri K, Sato A, Harunari T, Shimojo N, Yamaguchi I, Aonuma K. Impact of rivaroxaban compared with warfarin on } \\
\text { the coagulation status in Japanese patients with non-valvular atrial fibrillation: a preliminary analysis of the } \\
\text { prothrombin fragment } 1+2 \text { levels. J Cardiol } 2014 \text {. doi: } 10.1016 / j \text {.jjcc. } 2014.08 .006\end{array}$ \\
\hline 109 & $\begin{array}{l}\text { Dale BJ, Ginsberg JS, Johnston M, Hirsh J, Weitz JI, Eikelboom JW. Comparison of the effects of apixaban and } \\
\text { rivaroxaban on prothrombin and activated partial thromboplastin times using various reagents. J Thromb } \\
\text { Haemost } 2014 ; 12(11): 1810-1815\end{array}$ \\
\hline
\end{tabular}


Appendix A (Continued)

\begin{tabular}{|c|c|}
\hline $\begin{array}{l}\text { Appendix } \\
\text { reference } \\
\text { number }\end{array}$ & Reference citation \\
\hline 110 & $\begin{array}{l}\text { Czubek U, Góralczyk T, Zalewski J, Undas A. Monitoring of anticoagulant effects of dabigatran in everyday } \\
\text { practice: first experience in } 32 \text { Polish patients. Pol Arch Med Wewn 2014;124(9):487-489 }\end{array}$ \\
\hline 111 & $\begin{array}{l}\text { Van Blerk M, Bailleul E, Chatelain B, et al. Influence of dabigatran and rivaroxaban on routine coagulation assays. A } \\
\text { nationwide Belgian survey. Thromb Haemost 2015;113(1):154-164 }\end{array}$ \\
\hline 112 & $\begin{array}{l}\text { Levi M, Moore KT, Castillejos CF, et al. Comparison of three-factor and four-factor prothrombin complex } \\
\text { concentrates regarding reversal of the anticoagulant effects of rivaroxaban in healthy volunteers. J Thromb } \\
\text { Haemost } 2014 ; 12: 1428-1436\end{array}$ \\
\hline 113 & $\begin{array}{l}\text { Martinuzzo ME, Barrera LH, D'adamo MA, Otaso JC, Gimenez MI, Oyhamburu J. Frequent False-positive results of } \\
\text { lupus anticoagulant tests in plasmas of patients receiving the new oral anticoagulants and enoxaparin. Int J Lab } \\
\text { Hematol 2014;36:144-150 }\end{array}$ \\
\hline 114 & $\begin{array}{l}\text { Perzborn E, Heitmeier S, Laux V, Buchmüller A. Reversal of rivaroxaban-induced anticoagulation with pro- } \\
\text { thrombin complex concentrate, activated prothrombin complex concentrate and recombinant activated factor } \\
\text { VII in vitro. Thromb Res } 2014 ; 133: 671-681\end{array}$ \\
\hline 115 & $\begin{array}{l}\text { Francart SJ, Hawes EM, Deal AM, et al. Performance of coagulation tests in patients on therapeutic doses of } \\
\text { rivaroxaban. A cross-sectional pharmacodynamic study based on peak and trough plasma levels. Thromb } \\
\text { Haemost } 2014 ; 111: 1133-1140\end{array}$ \\
\hline 116 & $\begin{array}{l}\text { Visino F, Zaccaria F, Semeraro N, Colucci M. A modified prothrombin time to measure the anticoagulant activity of } \\
\text { dabigatran. Thromb Res 2014;134:1368-1369 }\end{array}$ \\
\hline 117 & $\begin{array}{l}\text { Dinkelaar J, Patiwael S, Harenberg J, Leyte A, Brinkman HJ. Global coagulation tests: their applicability for } \\
\text { measuring direct factor Xa- and thrombin inhibition and reversal of anticoagulation by prothrombin complex } \\
\text { concentrate. Clin Chem Lab Med 2014; 52(11):1615-1623 }\end{array}$ \\
\hline 118 & $\begin{array}{l}\text { Harenberg J, Du S, Weiss C, Krämer R, Hoppensteadt D, Walenga J; working party: methods to determine } \\
\text { apixaban of the Subcommittee on Control of Anticoagulation of the International Society of Thrombosis and } \\
\text { Haemostasis. Report of the Subcommittee on Control of Anticoagulation on the determination of the } \\
\text { anticoagulant effects of apixaban: communication from the SSC of the ISTH. J Thromb Haemost 2014;12: } \\
801-804\end{array}$ \\
\hline 119 & $\begin{array}{l}\text { Gosselin RC, Adcock Funk DM, Taylor JM, et al. Comparison of anti-Xa and dilute Russell viper venom time assays in } \\
\text { quantifying drug levels in patients on therapeutic doses of rivaroxaban. Arch Pathol Lab Med 2014;138: } \\
1680-1684\end{array}$ \\
\hline 120 & $\begin{array}{l}\text { Altman R, Gonzalez CD. Simple and rapid assay for effect of the new oral anticoagulant (NOAC) rivaroxaban: } \\
\text { preliminary results support further tests with all NOACs. Thromb J 2014;12(1):7 }\end{array}$ \\
\hline 121 & $\begin{array}{l}\text { Arachchillage DR, Efthymiou M, Lawrie AS, Machin SJ, Mackie IJ, Cohen H. Comparative sensitivity of commonly } \\
\text { used thromboplastins to ex vivo therapeutic rivaroxaban levels. Thromb Haemost 2014;112:421-423 }\end{array}$ \\
\hline 122 & $\begin{array}{l}\text { Lippi G, Favaloro EJ. Recent guidelines and recommendations for laboratory assessment of the direct oral } \\
\text { anticoagulants (DOACs): is there consensus? Clin Chem Lab Med 2015;53(2):185-197 }\end{array}$ \\
\hline 123 & $\begin{array}{l}\text { Ogata K, Mendell-Harary J, Tachibana M, et al. Clinical safety, tolerability, pharmacokinetics, and pharmacody- } \\
\text { namics of the novel factor Xa inhibitor edoxaban in healthy volunteers. J Clin Pharmacol 2010;50(7):743-753 }\end{array}$ \\
\hline 124 & $\begin{array}{l}\text { Bonar R, Favaloro EJ, Marsden K; RCPAQAP Haematology Haemostasis Committee. Dabigatran special exercise } \\
\text { report. Issued April, 2014. RCPA Quality Assurance Programs Pty Limited. St Leonards, NSW, Australia }\end{array}$ \\
\hline 125 & $\begin{array}{l}\text { Bonar R, Favaloro EJ, Marsden K; RCPAQAP Haematology Haemostasis Committee. Apixaban and Rivaroxaban } \\
\text { Trial Report. Issued December, 2014. RCPA Quality Assurance Programs Pty Limited. St Leonards, NSW, Australia }\end{array}$ \\
\hline
\end{tabular}

